\title{
American Chemical Society
}

\section{DOE/Project SEED Student Scholars Partnership Grant Number DE-FG01-90CE90043}

\author{
Report for Year V \\ $(6 / 7 / 94-4 / 27 / 95)$ \\ and \\ Final Report
}

\author{
June 13, 1995
}

\section{DISCLAIMER}

This report was prepared as an account of work sponsored by an agency of the United States Government. Neither the United States Government nor any agency thereof, nor any of their employees, makes any warranty, express or implied, or assumes any legal liability or responsibility for the accuracy, completeness, or usefulness of any information, apparatus, product, or process disclosed, or represents that its use would not infringe privately owned rights. Reference herein to any specific commercial product, process, or service by trade name, trademark, manufacturer, or otherwise does not necessarily constitute or imply its endorsement, recommendation, or favoring by the United States Government or any agency thereof. The views and opinions of authors expressed herein do not necessarily state or reflect those of the United States Government or any agency thereof. 


\section{REPORT YEAR V}

$$
\text { 6/7/94 - 4/27/95 }
$$




\section{DISCLAIMER}

Portions of this document may be illegible in electronic image products. Images are produced from the best available original document. 
The American Chemical Society

\section{PROJECT SEED PROGRAM}

Los Alamos National Laboratory

Summer ' 94 Session 
Report Index

I. Program Description

II. Program Organization

III. Recruitment and Placement

IV. Operation

V. Evaluation

VI. Highlights

VII. Attachments 


\section{Program Description}

Project SEED is an innovative career development activity administered by the American Chemical Society for economically disadvantaged high school students. SEED students spend ten weeks during the summer in an academic, industrial, or governmental research laboratory working under the supervision of a researcher or research assistant. The primary objective of Project SEED is to encourage participants to pursue strong academic programs and to more fully develop their career potential. The intent of the program is not to create scientists. Rather, it attempts to overcome some of the obstacles - social, institutional, attitudinal, and educational - which have traditionally excluded the economically disadvantaged from preparation for and entrance into professional careers.

The summer experience was designed to involve students in meaningful research supplemented with educational activities that included tours of selected Laboratory facilities, career and financial aid counseling for post-secondary training, and oral and written communications skills development. Students are required to prepare a technical summary, give presentations to their sponsoring groups and design and display a poster session. Two Project Seed II students and two Project SEED I students were selected to present their posters at the Sci-Mix poster session at the American Chemical Society's fall national meeting in Washington, D.C. In addition to Sci-Mix, the American Chemical Society arranged a tour of the "Science in American Life" exhibit at the Smithsonian Museum of American History and the students were able to visit the "Hands On Science Center".

\section{Program Organizaton}

\section{Laboratory Mentors:}

Six divisions, (MTL, CST, ESH, JCl, EES, and LS), where research is conducted that involves chemistry, and which have unclassified areas where students may be located, were identified to solicit project descriptions and student requests. Potential mentors were contacted and asked to submit project descriptions, appropriate for a high school student with one completed course in chemistry. The projects had to incorporate learning objectives and training opportunities on laboratory instumentation.

\section{Educational Activities:}

Tours of selected Laboratory research facilities were particularly popular. Representative tours were selected that gave the students an overview of the different kinds of research conducted at Los Alamos.

The tours were:

Superconductor research at the Materials Science Superconductor Facility

Thin Rock Section production at the EES 1 Facility

Los Alamos National Laboratory science history and research projects at the Bradbury Science Museum. 
Medium energy particle physics at the Los Alamos Meson Physics Facility (LAMPF)

Neutron beams for research in materials science, condensed-matter physics, polymer physics, chemistry, biology, and national security programs at the Los Alamos Neutron Scattering Center (LANSCE)

At each location, Laboratory staff provided briefings and, since the group was small, the presentations were geared to individual students and their personal interests.

Career Guidance:

ACS provided several booklets on Careers in Chemistry and the students attended a career class at the University of New Mexico at Los Alamos where they received concurrent high school and college credit. The instuctor for this class was Dolores Fuentes Guzman who devoted the class to career interests and the educational requirements accompanying these career choices. Steve Ciddio, UNM-LA career counselor, gave a presentation and invited the students to arrange individual appointments to further discuss their college plans and resources.

In the classroom of UNM-LA, the Project SEED students set up a career bulletin board where the students could receive career information from the ACS as well as information on the research that they were engaged in. Articles on careers in chemistry supplied by the ACS as well as the Los Alamos National Laboratory were displayed on the bulletin board. Information on finding financial aid and a list of the 1994 approved schools for Project SEED students to apply for scholarships was provided by ACS. Students found the "mentor help hotline" useful for dealing with any problems that may have come up with their mentors during the course of their summer research experience.

Financial Aid:

ACS has offered to assist Project SEED participants with scholarship/grant information and has encouraged has encouraged students to contact them. One Project SEED II student has written the ACS in Washington, D.C., for assistance in receiving financial aid for college. In their post-program questionaire, mentors were asked to recommend students for assistance. Each student also received a directory of scholarships available specifically for minorities. The students were informed of the various types of scholarships and grants and instructed on how to complete the general financial aid form.

\section{Communications Skills Development:}

Each participant was required to prepare a technical summary, (8-9 pgs. avg.), of what they had learned during their summer experience. The students prepared outlines, rough drafts for editing then submitted their final reports. The students were also required to design and display a poster session illustrating their summer experience. Except for three Project SEED II students, the participants had no prevoius experience preparing a poster session, so several instructional sessions were included. The posters were displayed at a program closing reception attended by families, mentors, other lab personnel, Science Education \& Outreach staff, and LANL scientists who served as guides for varoius tours that the students took during the summer. Four of the students vere selected to present their posters at the Sci-Mix poster session at the ACS fall national meeting in Washington, 
D.C. Sci-Mix is an interdiciplanary poster session which draws a large group of chemists. Many found the posters of the SEED students interesting and engaged the students in discussion without realizing that they were still in high school or starting college. The SEED students found the Sci-Mix poster session to be a great experience and enjoyed the "Science in American Life" exhibit at the Smithsonian Museum.

The students received several instructional sessions to improve their oral communication skills.

Many of the students had not presented a scientific talk and were hesitant to present their research experience in front of their peers and sponsoring groups. Video taping their presentations and going over the tape with the SEED students individually helped polish their presentations and allowed the students to enhance their oral communications skills.

Site Visits:

To monitor the students' progress, and to establish substantial communications ties with mentors, students were visited frequently at their work locations. This permitted students to discuss any problem areas but to offer comments and suggestions.

Evaluation

ACS requires a post-program survey which provides information for a national survey. On this survey, Project SEED students were asked to indicate their response to statements on how the program helped them. The following statements were:

Project SEED helped me:

Discover skills and abilities

Develop self-confidence

Develop responsibility

Develop better study habits

Learn what advanced study is like

Understand the purpose of scientific research

Understand how scientific research is done

Understand the ethical behavoir of scientists pursuing and reproting research

Develop a greater interest in scientific/technical areas

Decide to continue my education after high school

Choose a college major

Learn about employment opportunities in scientific/techniclal fields

Decide to pursue a career in a scientific/techniclal field

The students were to indicate "Agree", "Neutral", or "Disagree" to the statements. 76\% of the responses were "Agree", 22\% were "Neutral", and 2\% were "Disagree".

Students were also asked to indicate the amount of education they planned to complete. After the program $91 \%$ indicated they were now planning to complete more education than they had previously planned. Most typically, students now are thinking about training in a graduate program.

When asked how they would rate the overall Project SEED program (based on "great", 
"pretty good", "not bad", "pretty bad", or "awful") 11 students rated the program "great", and 1 rated it "pretty good".

An accompanying LANL-SEED pre- and post-program survey was also administered to gather information on our particular program. When asked what they hoped to get out of the program, 8 of the student $(66.6 \%)$ indicated they wanted to gain knowledge in science. $2(16.6 \%)$ hoped to learn laboratory procedures and $2(16.6 \%)$ hoped to learn more chemistry. When asked what they gained from the program, the resposes were more varied: all stated they had learned a lot, however, they clarified this into the following comments:

"I gained an understanding of research in many different fields of science"

"I received hands on experience with state of the art equipment, learned many techniques" "Experience in a lab, more knowledge of chemistry, greater interest in chemistry, information cis college, and knowledge of what other types of research occurs at LANL" "I was allowed the opportunity to study science in the real world. I gained experience and confidence"

"I gained lots of knowledge on different types of science that I would never have received in school"

"How to communicate with other people in my lab"

"l gained insight on what it would be like working with professional scientists"

"I gained an insight to lasers and some of the functions as well as research experience and college survival skills"-

"I learned some math. I also know a little more on what career I want to pursue, because of the class at UNM-LA"

"This summer I gained experience in working in a biochemisrty lab. I also gained insight in working with cells which will help me in future classes. I also learned about other things at the tours on Fridays"

"I gained a sense of insight into chemical science... what it was all about and-its significance. Also the tours were great"

"Experience, knowledge, and lots of memories. I liked the tours because they showed us many interesting things"

The program did not increase the students' educational goals significantly (only two students changed from "vocational institute" and "get a job" to "college"). It was good to see that these two students realized the importance of getting a good education in order to accomplish and attain their goals in life. The science interests of the students, however, changed somewhat. On the pre-program survey, 7 students $(58.3 \%)$ said chemistry was their most interesting science field, 4 students (33.3\%) said biology and one said physics $(8.3 \%)$. On the post-program survey, 10 students $(83.3 \%)$ stated that chemistry is their most interesting field, and two students $(16.6 \%)$ are interested in biology.

The program seemed to increase the student's interest in chemistry while exposing the students to new applications of science and showed them how science is used to solve problems. 
Problems - Actions:

1) Research position Requests:

A better selection of student projects is desirable. Groups need more advance information and more potential mentors need to be contacted to increase the number of student projects.

\section{2) Student recruitment:}

Recruitment of students was a problem. This year schools were not visited by a representative of the Project SEED program so the number of students applying was low. Mentors did not have many applications to make a decission from. Next year, more time needs to be set aside to recruit properly possible using Project SEED students from this past summer to inform their fellow classmates on the benefits of the program.

More schools and institutions need to be informed about Project SEED so that all students near the Los Alamos National Laboratory who meet the program qualifications may apply for the program. This includes Indian schools and small rural schools who may have been overlooked in the past.

\section{3) Student placement:}

Only one of the Project SEED students was able to interview with a potential mentor before the summer started. Other mentors liked the idea of being able to interview the students before making a selection. Time needs to be set aside for this process to happen and the number of applicants needs to be increased.

Program Highlights:

The poster session, held on August 9, was well attended and students were proud of their displays. Several students indicated that they were considering using their projects for science fair competition during the school year. Several students expressed an interest in displaying their posters at the Sci-Mix poater session at the ACS fall national meeting.

The students' technical reports were well written and they will be compiled into a booklet for the participants.

One of the Project SEED students was selected to participate in the '94-'95 HS COOP program.

Two Project SEED II students and two Project SEED I students were selected to present their posters at the Sci-Mix poster session at the American Chemical Society's fall national meeting in Washington, D.C. In addition to Sci-Mix, the American Chemical Society arranged a tour of the "Science in American Life" exhibit at the Smithsonian Museum of American History and the students were able to visit the "Hands On Science Center". 
At the end of the program, the students were asked to list any program highlights. The following are their comments:

"I' $d$ like to say that the program is enriching, beneficial, and has made me

- enthusiastic about science careers"

"The tours we took were great and I learned a lot. I hope to be able to participate in Project SEED II next-summer"

"I enjoyed the summer program. It was interesting and it showed me responsibility, patience, and most of all it gave me the experience of a lifetime"

"Working at the Laboratory and the-tours-were very-interesting and the class was helpful for preperation of college"

"I love my mentor and the people in my lab"

"I commend the ACS Project SEED organizers for bringing such a great program to excellent institutions like the Los Alamos National Laboratory" 
American Chemical Society

PROJECT SEED PROGRAM

Los Alamos National Laboratory

Summer '94 Session

\begin{tabular}{|c|c|c|c|c|}
\hline Student/School & Sex & Ethnicity & Family Size & Research Topic/Mentor \\
\hline $\begin{array}{l}\text { Patrick Lopez } \\
\text { Penasco High School }\end{array}$ & $M$ & Hispanic & 5 & $\begin{array}{l}\text { Non-Invasive Waste } \\
\text { Drum Pressure } \\
\text { Detection - Rodger } \\
\text { Tennant, CST-2 } \\
\end{array}$ \\
\hline $\begin{array}{l}\text { Lorenzo Lovato } \\
\text { Espanola Valley High } \\
\text { School }\end{array}$ & $M$ & Hispanic & 1 & $\begin{array}{l}\text { Gas Separation Using } \\
\text { Electronically } \\
\text { Conductive Polymers: } \\
\text { A Study of Polyanaline - } \\
\text { Ben Mattes, MTL-11 }\end{array}$ \\
\hline $\begin{array}{l}\text { Bryan Velasquez } \\
\text { Coronado High School }\end{array}$ & M & Hispanic & 5 & $\begin{array}{l}\text { Monitoring Tritium } \\
\text { Contamination with } \\
\text { Honey Bees at Los } \\
\text { Alamos National } \\
\text { Laboratory - Phil } \\
\text { Fresquez, ESH-8 }\end{array}$ \\
\hline $\begin{array}{l}\text { Anika Abdul-HaQQ } \\
\text { Espanola Valley High } \\
\text { School }\end{array}$ & $\mathbf{F}$ & African American & 7 & $\begin{array}{l}\text { Characterization of } \\
\text { Steptococus from } \\
\text { Frijoles Creek - Marke } \\
\text { Talley, JCl }\end{array}$ \\
\hline $\begin{array}{l}\text { Miguel Baca } \\
\text { Penasco High School }\end{array}$ & M & Hispanic & 7 & $\begin{array}{l}\text { Yucca Mountain: } \\
\text { Sorption of Strontium - } \\
\text { Stephen Kung, CST-10 }\end{array}$ \\
\hline
\end{tabular}




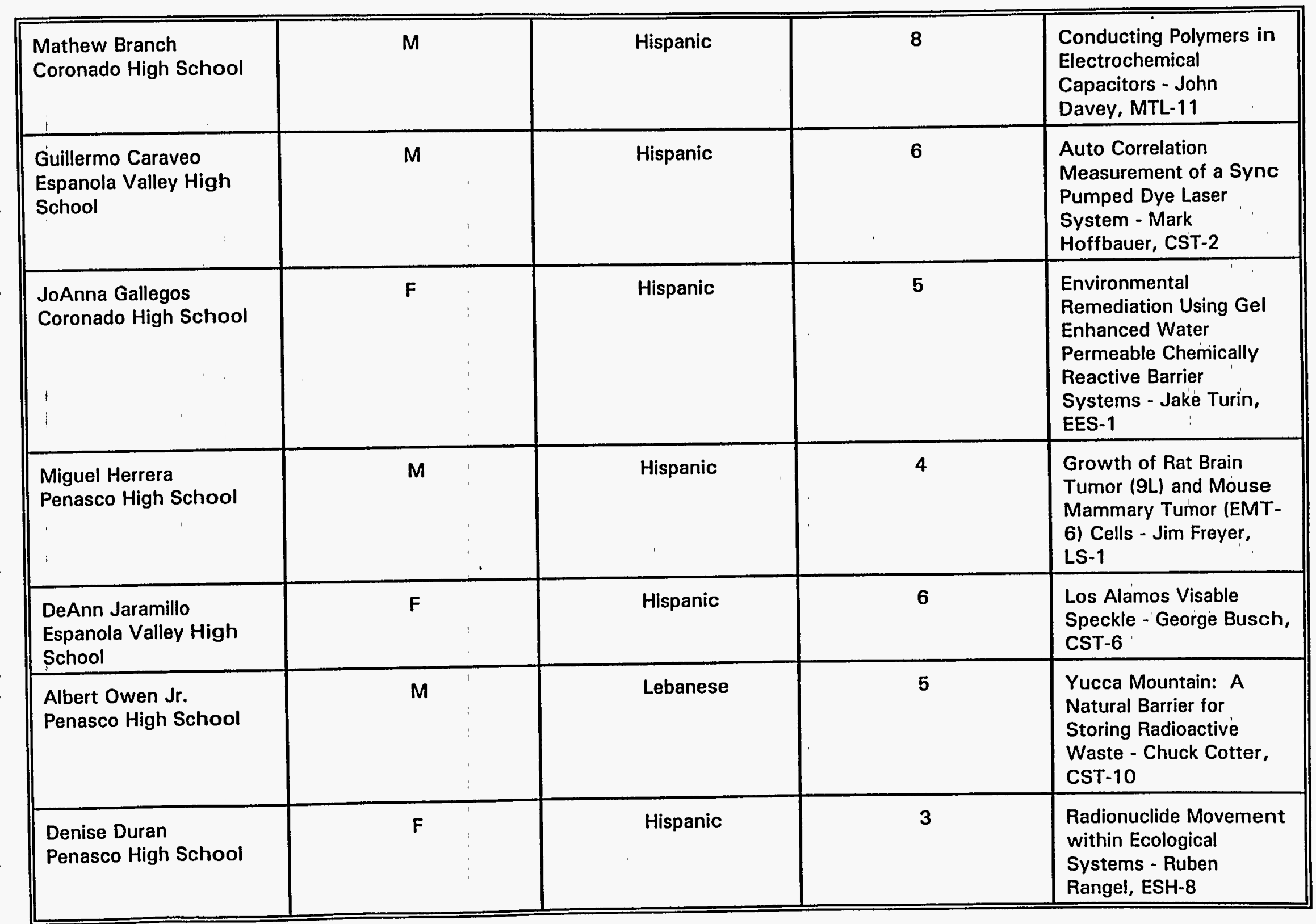


Attachment Index

Participant Profiles

Program Fact Sheet

ACS Program Guidelines

Sample Project Description

Pre and Post-program Surveys

Sample Student Papers

Poster Session Pamphlet

Flyer for Poster Session (Los Alamos National Laboratory)

Flyer for Poster Session (ACS Sci-Mix, Washington, D.C.)

Letters from Project SEED students who went to the Sci-Mix Poster Session

News Release - "SEED Students Get National Show-And-Tell Session"

Letter of Support from the Central New Mexico Section of the American Chemical Society 


LOS ALAMOS NATIONAL LABORATORY
PROJECT SEED PROGRAM PROFILE FOR 1994
Student Programs
NAME OF PERSON COMPLETING TEMPLATE: Joseph Vigil_ DATE: Sept. 13, 1994

Actual Column - The information given in this column was obtained from surveys and interviews from all participants of the Project SEED program.

1. Program Design:

\begin{tabular}{|c|c|c|}
\hline COMPONENTS COLUMN & INTENDED COLUMN & ACTUAL COLUMN \\
\hline $\begin{array}{l}\text { a. Program goals are clear } \\
\text { and understood by all. }\end{array}$ & $\begin{array}{l}\text { a. Goals are clearly stated } \\
\text { in the recruitment flyers, } \\
\text { orally presented during the } \\
\text { orientation which took } \\
\text { place on the morning of the } \\
\text { first day of the program. } \\
\text { Students received hand- } \\
\text { outs at the end of the } \\
\text { summer emphasizing } \\
\text { program goals. }\end{array}$ & $\begin{array}{l}\text { a. Participants clearly- } \\
\text { described the goals of the } \\
\text { program. Students and } \\
\text { mentors emphasized } \\
\text { different goals, but } \\
\text { generally got them all. }\end{array}$ \\
\hline $\begin{array}{l}\text { b. Teachers, } \\
\text { administrators, scientists, } \\
\text { and others are involved in } \\
\text { program design and } \\
\text { implementation. }\end{array}$ & $\begin{array}{l}\text { b. Administrators and } \\
\text { faculty from UNM-LA } \\
\text { jointly design course } \\
\text { sequence with Project } \\
\text { SEED coordinator. UNM- } \\
\text { LA provides staff for career } \\
\text { advisement. LANL scientist, } \\
\text { UNM faculty, and project } \\
\text { staff jointly design the } \\
\text { summer program. }\end{array}$ & $\begin{array}{l}\text { b. Interviews with the } \\
\text { program coordinator clearly } \\
\text { indicates that the design of } \\
\text { the program was a joint } \\
\text { effort between the } \\
\text { American Chemical } \\
\text { Society, project staff, } \\
\text { LANL scientists, and UNM } \\
\text { faculty. }\end{array}$ \\
\hline $\begin{array}{l}\text { c. The environment is safe } \\
\text { and supportive. }\end{array}$ & $\begin{array}{l}\text { c. } 80 \% \text { of the students } \\
\text { time is spent in a Lab with } \\
\text { their mentors. The Los } \\
\text { Alamos National Laboratory } \\
\text { insures a safe working } \\
\text { place for all employees and } \\
\text {-visitors. Site visitis were } \\
\text { conducted to make sure } \\
\text { students worked in a safe } \\
\text { and supportive } \\
\text { environment. }\end{array}$ & $\begin{array}{l}\text { c. All participants } \\
\text { interviewed said they felt } \\
\text { comfortable and safe in } \\
\text { their lab setting which } \\
\text { included their classroom at } \\
\text { UNM-LA and while on } \\
\text { tours at the Los Alamos } \\
\text { National Laboratory. }\end{array}$ \\
\hline
\end{tabular}




\begin{tabular}{|c|c|c|}
\hline $\begin{array}{l}\text { d. Program interacts, } \\
\text { collaborates and networks } \\
\text { with other programs, local } \\
\text { school districts, and } \\
\text { universities. }\end{array}$ & $\begin{array}{l}\text { d. The program was } \\
\text { designed to interact with } \\
\text { other programs at the Los } \\
\text { Alamos National } \\
\text { Laboratory, such as the } \\
\text { Science Education \& } \\
\text { Outreach PRISM program. } \\
\text { The Project SEED students } \\
\text { spent an afternoon with the } \\
\text { PRISM students listening to } \\
\text { presentations by LANL } \\
\text { scientists and interviewing } \\
\text { them about science career } \\
\text { choices. Recruitment of } \\
\text { participants involves the } \\
\text { cooperation of local school } \\
\text { districts and arrangements } \\
\text { were made with the } \\
\text { University of New Mexico } \\
\text { at Los Alamos for the } \\
\text { students to receive } \\
\text { university credit for } \\
\text { successful completion of } \\
\text { the program. Since the } \\
\text { students were enrolled in } \\
\text { UNM-LA, they were } \\
\text { allowed to use the library } \\
\text { and computer labs on } \\
\text { campus. Students also } \\
\text { took advantage of the } \\
\text { career resource center. }\end{array}$ & d. As intended \\
\hline
\end{tabular}

\section{Student Selection:}

\begin{tabular}{||l|l|l||}
\hline COMPONENTS COLUMN & \multicolumn{1}{|c|}{ INTENDED COLUMN } & \multicolumn{1}{|c|}{ ACTUAL COLUMN } \\
\hline $\begin{array}{l}\text { a. Clear criteria related to } \\
\text { program goals are } \\
\text { established and used for } \\
\text { student selection. }\end{array}$ & $\begin{array}{l}\text { a. Eligibility criteria is } \\
\text { stated on all recruitment } \\
\text { materials. Participants are } \\
\text { identified through teacher } \\
\text { recommendations, } \\
\text { academic qualifications, } \\
\text { completion of one year of } \\
\text { chemistry, and personal } \\
\text { essay on why they want to } \\
\text { participate in Project SEED. }\end{array}$ & $\begin{array}{l}\text { all of the participants } \\
\text { having completed a year of } \\
\text { chemistry and as having an } \\
\text { interest in careers } \\
\text { associated with chemistry. } \\
\text { SEED coordinator matched } \\
\text { applications to project } \\
\text { descriptions and mentors } \\
\text { make final selections. }\end{array}$ \\
\hline
\end{tabular}




\begin{tabular}{||l|l|l||}
\hline $\begin{array}{l}\text { b. Criteria for selection } \\
\text { include the support of a } \\
\text { teacher or mentor from } \\
\text { school or community } \\
\text { before program (for } \\
\text { recommendation) and after } \\
\text { (for continuous application } \\
\text { of learnings from program) }\end{array}$ & $\begin{array}{l}\text { b. Teacher } \\
\text { recommendations are used } \\
\text { but are only one criterion } \\
\text { for student selection }\end{array}$ & $\begin{array}{l}\text { b. Program coordinator } \\
\text { includes teacher } \\
\text { recommendations in the } \\
\text { selction process. }\end{array}$ \\
\hline $\begin{array}{l}\text { c. Active outreach and } \\
\text { recruitment targets } \\
\text { students who are at-risk } \\
\text { and those from groups } \\
\text { underrepresented in } \\
\text { science, mathematics, and } \\
\text { technology. }\end{array}$ & $\begin{array}{l}\text { c. Recruitment efforts } \\
\text { throughout the target } \\
\text { region resulted in } \\
\text { applications that were } \\
\text { predominantly from } \\
\text { underrepresented groups, } \\
\text { mostly Hispanic and Native } \\
\text { American.Recruitment } \\
\text { targets students who come } \\
\text { from economically } \\
\text { disadvantaged families. }\end{array}$ & c. As intended \\
\hline
\end{tabular}

3. Preparation:

\begin{tabular}{||l|l|l||}
\hline COMPONENTS COLUMN & \multicolumn{1}{|c|}{ INTENDED COLUMN } & \multicolumn{1}{|c|}{ ACTUAL COLUMN } \\
\hline $\begin{array}{l}\text { a. Students are oriented to } \\
\text { their role and the nature of } \\
\text { their experience, to the Lab } \\
\text { environment, and to the } \\
\text { Department of Energy/Lab } \\
\text { mission and competencies, } \\
\text { using grade-level } \\
\text { appropriate language }\end{array}$ & $\begin{array}{l}\text { a. Students were oriented } \\
\text { to their role and the nature } \\
\text { of the Project SEED } \\
\text { Orientation session on the } \\
\text { first morning of the } \\
\text { program. SEED } \\
\text { participants also attended a } \\
\text { General Employee Training } \\
\text { during the first week of the } \\
\text { program to orient them to } \\
\text { the Lab environment. Site } \\
\text { specific training was given } \\
\text { well prepared to begin the } \\
\text { program. Many of the } \\
\text { students felt overwhelmed } \\
\text { by all the instruments and } \\
\text { chemistry that they needed } \\
\text { to know. After a few } \\
\text { weeks, the students } \\
\text { started to become } \\
\text { accustumed to working in } \\
\text { their labs. } \\
\text { training needs. During the } \\
\text { course of the program the } \\
\text { selected presenters and } \\
\text { tour guides continued to } \\
\text { provide the students with } \\
\text { information about the lab's } \\
\text { mission and competencies. }\end{array}$ & \\
\hline & & \\
& &
\end{tabular}




\begin{tabular}{|c|c|c|}
\hline $\begin{array}{l}\text { b. Program administator(s), } \\
\text { students, teachers, and } \\
\text { parents establish mutual } \\
\text { expectations in advance. }\end{array}$ & $\begin{array}{l}\text { b. Students' expectations } \\
\text { of the program were } \\
\text { solicited in their program } \\
\text { applications. These } \\
\text { expectations were taken } \\
\text { into consideraton in } \\
\text { program design, specifically } \\
\text { when setting up tours and } \\
\text { presentors. Students } \\
\text { accepted to the program } \\
\text { were informed of and } \\
\text { agreed to the expectations } \\
\text { of the program. The } \\
\text { students were expected be } \\
\text { responsible for attendance, } \\
\text { transportation, participation } \\
\text { of all activities on Friday } \\
\text { afternoon, and lunch. } \\
\text { parents were also informed } \\
\text { of these expectations and } \\
\text { signed a consent form for } \\
\text { their child. Presenters and } \\
\text { tour guides were informed } \\
\text { in advance of the goals of } \\
\text { the program and our } \\
\text { expectations concerning } \\
\text { the presentation and } \\
\text { student envolvement. }\end{array}$ & $\begin{array}{l}\text { b. All the students except } \\
\text { one said that their } \\
\text { expectations were met. } \\
\text { The remaining individual } \\
\text { stated that their was too } \\
\text { much chemistry in his } \\
\text { project. Even though the } \\
\text { program required a year of } \\
\text { chemistry and a genuine } \\
\text { interest, as the summer } \\
\text { progressed the student } \\
\text { found that his research } \\
\text { project contained too high } \\
\text { a level of chemistry. }\end{array}$ \\
\hline $\begin{array}{l}\text { c. Students receive } \\
\text { background materials or } \\
\text { orientation in advance. }\end{array}$ & $\begin{array}{l}\text { c. The orientation agenda } \\
\text { (with a detailed map of } \\
\text { location of the orientation), } \\
\text { financial aid information, } \\
\text { and brochures describing } \\
\text { the various research } \\
\text { projects at the Los Alamos } \\
\text { National Laboratory are } \\
\text { mailed to the participants } \\
\text { prior to their arrival for the } \\
\text { Project SEED program. } \\
\text { Parent consent forms are } \\
\text { also sent to the participants } \\
\text { and asked to be returned to } \\
\text { the program coordinator at } \\
\text { the orientation. }\end{array}$ & c. As intended \\
\hline
\end{tabular}




\begin{tabular}{|l|l|l||}
\hline $\begin{array}{l}\text { d. Students receive } \\
\text { advance communication } \\
\text { about logistics and } \\
\text { housing, when appropriate. }\end{array}$ & $\begin{array}{l}\text { d. The students received } \\
\text { agendas, meeting locations, } \\
\text { and car pooling infromation } \\
\text { prior to the start of the } \\
\text { program. Housing } \\
\text { information was not needed } \\
\text { since the students were all } \\
\text { in commuting distance from } \\
\text { the Los Alamos National } \\
\text { Laboratory. }\end{array}$ & d. As intended \\
\hline $\begin{array}{l}\text { e. Program establishes } \\
\text { relationship with student's } \\
\text { teacher, school, and/or } \\
\text { district. }\end{array}$ & $\begin{array}{l}\text { e. recruitment occurred at } \\
\text { target schools and school } \\
\text { staff assisted with student } \\
\text { applications. }\end{array}$ & e. As intended \\
\hline $\begin{array}{l}\text { f. Program selects, orients, } \\
\text { and trains and associates } \\
\text { to ensure that they } \\
\text { understand the goals and } \\
\text { nature of the program and } \\
\text { apply the most appropriate } \\
\text { knowledge, skills, } \\
\text { attitudes, and stratagies to } \\
\text { their work with student } \\
\text { particiapnts. }\end{array}$ & $\begin{array}{l}\text { f. Mentors must submit a } \\
\text { project description to the } \\
\text { AcS for approval. The } \\
\text { presentors/tour guides are } \\
\text { informed of the goals and } \\
\text { nature of the program. } \\
\text { Since the Project SEED } \\
\text { group is so small, the } \\
\text { presentations were geared } \\
\text { to individual students and } \\
\text { their personal interests. }\end{array}$ & $\begin{array}{l}\text { f. Students enjoyed their } \\
\text { reseaich experience and all } \\
\text { stated in the post-program } \\
\text { survey that their mentors } \\
\text { provided them with an } \\
\text { enriching summer. } \\
\text { Students found the } \\
\text { program staff helpful in } \\
\text { order to have a better } \\
\text { summer experience. }\end{array}$ \\
\hline
\end{tabular}

\section{Program Activities:}

\begin{tabular}{|c|c|c|}
\hline COMPONENTS COLUMN & INTENDED COLUMN & ACTUAL COLUMN \\
\hline $\begin{array}{l}\text { a. Complement or enhance } \\
\text { student's current science, } \\
\text { mathematics, and/or } \\
\text { technology curriculum. }\end{array}$ & $\begin{array}{l}\text { a. The students were } \\
\text { introduced to real world } \\
\text { scientific issues and } \\
\text { problems and allowed to } \\
\text { work on these problems as } \\
\text { a member of a scientific } \\
\text { team under the guidance of } \\
\text { a mentor. The program } \\
\text { was designed to give the } \\
\text { SEED students a research } \\
\text { experience much different } \\
\text { than what the students } \\
\text { experience academically at } \\
\text { their schools. }\end{array}$ & $\begin{array}{l}\text { a. Students stated in their } \\
\text { post-program surveys that } \\
\text { they could never have } \\
\text { received the experiences } \\
\text { that they received at Los } \\
\text { Alamos back at their } \\
\text { schools. The summer } \\
\text { experience covered a wide } \\
\text { range of science process } \\
\text { and social skills. } \\
\text { Participants received } \\
\text { instruction on such topics } \\
\text { as learning styles and } \\
\text { skills, presenting reports, } \\
\text { using library resources, and } \\
\text { designing experiments. }\end{array}$ \\
\hline
\end{tabular}




\begin{tabular}{|c|c|c|}
\hline $\begin{array}{l}\text { b. Involve students in } \\
\text { actually doing science, } \\
\text { through using tools, } \\
\text { methods, and processes of } \\
\text { scientists; demonstrate } \\
\text { that research has unknown } \\
\text { outcomes, uncertainties, } \\
\text { and loose ends. }\end{array}$ & $\begin{array}{l}\text { b. All of the Los Alamos } \\
\text { National Laboratory } \\
\text { scientists who presented or } \\
\text { gave the students tours } \\
\text { described and showed the } \\
\text { tools, methods, and } \\
\text { thought processes they use } \\
\text { in their research. The } \\
\text { scientists at the joint } \\
\text { Prism/Project SEED } \\
\text { presentations stressed to } \\
\text { the participants that } \\
\text { research is not a well- } \\
\text { defined process and does } \\
\text { not necessarily follow the } \\
\text { "scientific method". The } \\
\text { students worked in a lab } \\
\text { for ten weeks with their } \\
\text { mentor and experience first } \\
\text { hand how scientific } \\
\text { research is done at a world } \\
\text { class laboratory. }\end{array}$ & $\begin{array}{l}\text { b. All participants stated } \\
\text { in their post survey that } \\
\text { they gained an insight into } \\
\text { how scientists conduct } \\
\text { research. Students } \\
\text { stressed the importance of } \\
\text { communication with other } \\
\text { scientists and the team } \\
\text { work that takes place in } \\
\text { order to accomplish tasks } \\
\text { and goals. }\end{array}$ \\
\hline $\begin{array}{l}\text { c. Are appropriate for } \\
\text { individual student's } \\
\text { developmental level, } \\
\text { capability, gender, cultural } \\
\text { background, technical } \\
\text { skills, interests, language, } \\
\text { and learning style. }\end{array}$ & $\begin{array}{l}\text { c. The } 1994 \text { Project SEED } \\
\text { students made up a wide } \\
\text { range of developmental } \\
\text { levels, cultural } \\
\text { backgrounds, technical } \\
\text { skills, interests, and } \\
\text { learning styles. The } \\
\text { program's activities ware } \\
\text { designed to include a } \\
\text { variety of diferent topics, } \\
\text { activities, learning } \\
\text { techniqiues, and cultural } \\
\text { references. Learning } \\
\text { techniques included } \\
\text { lectures, reading } \\
\text { assignments, library } \\
\text { research, group } \\
\text { presentations and tours, } \\
\text { problem solving activities, } \\
\text { and hands-on activities. In } \\
\text { addition, students were } \\
\text { given the unique } \\
\text { opportunity to particiapte in } \\
\text { current research under the } \\
\text { supervision of a LANL } \\
\text { mentor. }\end{array}$ & $\begin{array}{l}\text { c. Students stated that } \\
\text { they enjoeyed the wide } \\
\text { range of activities that } \\
\text { they participated in the ten } \\
\text { week long program. One } \\
\text { student stated the post } \\
\text { program survey that " the } \\
\text { program was an } \\
\text { experience of a lifetime". }\end{array}$ \\
\hline
\end{tabular}




\begin{tabular}{|c|c|c|}
\hline $\begin{array}{l}\text { d. Are challenging, } \\
\text { engaging, exciting, and } \\
\text { fun. }\end{array}$ & $\begin{array}{l}\text { d. The students were } \\
\text { challenged by the process } \\
\text { of conducting and being a } \\
\text { part a research project and } \\
\text { proposing solutions to real } \\
\text { world problems. Hands-on } \\
\text { activities and tours } \\
\text { engaged the students and } \\
\text { added fun and excitement. } \\
\text { The oportunity to meet } \\
\text { other students from other } \\
\text { programs added to the } \\
\text { students experience. The } \\
\text { four students selected to } \\
\text { go to the Sci-Mix poster } \\
\text { session in Washington, } \\
\text { D.C. found the trip and } \\
\text { poster presentation } \\
\text { challenging, engaging, } \\
\text { exciting, and fun. }\end{array}$ & $\begin{array}{l}\text { d. The mentors of the } \\
\text { project SEED students } \\
\text { stated that the students } \\
\text { were overwheimed at first, } \\
\text { but challenged with their } \\
\text { research. At the end of } \\
\text { the summer site visits } \\
\text { found all particiapants } \\
\text { totally engaged in their } \\
\text { research. Tours were } \\
\text { exciting and fun for the } \\
\text { students as indicated by } \\
\text { theri post-program } \\
\text { surveys. }\end{array}$ \\
\hline $\begin{array}{l}\text { e. Involve new } \\
\text { technologies. }\end{array}$ & $\begin{array}{l}\text { e. the Project SEED } \\
\text { students were exposed to, } \\
\text { and in all cases } \\
\text { experimented with new } \\
\text { technologies. Most of the } \\
\text { presentors and tour guides } \\
\text { provided the students with } \\
\text { examples of new } \\
\text { technology they use in their } \\
\text { research and in most cases } \\
\text { the students were able } \\
\text { toexperiment with them. }\end{array}$ & e. As intended \\
\hline $\begin{array}{l}\text { f. Have definable end- } \\
\text { products for students, such } \\
\text { as projects and } \\
\text { presentations to peers }\end{array}$ & $\begin{array}{l}\text { f. The students designed } \\
\text { and presented a poster } \\
\text { describing their research } \\
\text { experience as well as } \\
\text { submitted a technical paper } \\
\text { which they used to present } \\
\text { a technical talk for their } \\
\text { mentors and technicians } \\
\text { from their lab. Four } \\
\text { students were selected to } \\
\text { present their posters at the } \\
\text { national ACS convention in } \\
\text { Washington, D.C. }\end{array}$ & $\begin{array}{l}\text { f. Students stated that the } \\
\text { posters and papers were a } \\
\text { lot of work but enjoyed the } \\
\text { poster session and felt } \\
\text { they accomplished a lot. } \\
\text { Many of the students will } \\
\text { use their posters at } \\
\text { science fairs back at their } \\
\text { schools. }\end{array}$ \\
\hline
\end{tabular}




\begin{tabular}{|c|c|c|}
\hline $\begin{array}{l}\text { g. Assign students to a } \\
\text { team, modeling } \\
\text { interdependence and } \\
\text { collegiality (if a research } \\
\text { experience, students join } \\
\text { an existing research team } \\
\text { of scientists and other Lab } \\
\text { staff) }\end{array}$ & $\begin{array}{l}\text { g. Students worked with a } \\
\text { mentor, technicians, and } \\
\text { other students and teachers } \\
\text { from other programs. (Ex. } \\
\text { TRAC Teachers). The } \\
\text { students spent } 80 \% \text { of the } \\
\text { program working as a } \\
\text { member of a scientific team } \\
\text { to carry out their research. }\end{array}$ & $\begin{array}{l}\text { g. Students felt they were } \\
\text { part of a team. Many } \\
\text { stated that they would not } \\
\text { have been able to } \\
\text { experience as much as } \\
\text { they had without the help } \\
\text { and guidance of mentors } \\
\text { and technicians in their } \\
\text { lab. Many mentors stated } \\
\text { that the students helped } \\
\text { them in many ways. } \\
\text { Students were invited and } \\
\text { participated actively in } \\
\text { group, scientific meetings } \\
\text { where they presented their } \\
\text { part in the research project } \\
\text { and any results that were } \\
\text { obtained. }\end{array}$ \\
\hline $\begin{array}{l}\text { h. Assign students or } \\
\text { groups of students mentors } \\
\text { for guidance, support, } \\
\text { structure, role modeling, } \\
\text { etc. }\end{array}$ & $\begin{array}{l}\text { h. Each student was } \\
\text { assigned a mentor for the } \\
\text { summer program. The } \\
\text { mentors provided the } \\
\text { students with a research } \\
\text { project and provided } \\
\text { guidance, support, } \\
\text { structure, and acted as a } \\
\text { role model throughout the } \\
\text { summer. }\end{array}$ & $\begin{array}{l}\text { h. Mentors went beyond } \\
\text { the call of duty and will } \\
\text { continue to act as a } \\
\text { mentors even after the } \\
\text { program is done. One } \\
\text { mentor is even helping a } \\
\text { Project SEED II student } \\
\text { secure financial aid for } \\
\text { college. The mentors } \\
\text { serve as the backbone of } \\
\text { the program. }\end{array}$ \\
\hline $\begin{array}{l}\text { i. Provide opportunities for } \\
\text { developing knowledge of } \\
\text { important science } \\
\text { concepts, skills, and } \\
\text { "scientific habits of mind". }\end{array}$ & $\begin{array}{l}\text { i. The students developed } \\
\text { knowledge of science - } \\
\text { concepts, skills and } \\
\text { "scientific habits of mind" } \\
\text { through interacting with } \\
\text { presenters, reading } \\
\text { scientific literature, library } \\
\text { research, hands-on } \\
\text { activities, and through their } \\
\text { daily research experience } \\
\text { with their mentors. }\end{array}$ & i. As intended. \\
\hline
\end{tabular}




\begin{tabular}{|c|c|c|}
\hline $\begin{array}{l}\text { j. Expose students to } \\
\text { variety of careers identified } \\
\text { through research on future } \\
\text { job market. }\end{array}$ & $\begin{array}{l}\text { j. Students were exposed } \\
\text { to a variety of scientific } \\
\text { and technical careers by } \\
\text { their interactions with } \\
\text { LANL staff and UNM-LA } \\
\text { career classes. The ACS } \\
\text { sent numerous pamphlets } \\
\text { on chemistry careers } \\
\text { featuring the careers in } \\
\text { chemistry that will be in } \\
\text { demand in the future job } \\
\text { market. Articles on careers } \\
\text { were posted on the Project } \\
\text { SEED student bulletin } \\
\text { board. }\end{array}$ & $\begin{array}{l}\text { j. All students interviewed } \\
\text { felt they had been exposed } \\
\text { to numerous scientific, } \\
\text { specifically chemistry, } \\
\text { careers during the course } \\
\text { of the program. Pre- and } \\
\text { post-surveys showed that } \\
\text { the program sparked an } \\
\text { interest in chemistry } \\
\text { careers. The students aiso } \\
\text { took a tour of the Bradbury } \\
\text { Science Museum where } \\
\text { the tour guide pointed out } \\
\text { the various science careers } \\
\text { that the students could go } \\
\text { into. }\end{array}$ \\
\hline $\begin{array}{l}\text { k. Provide opportunities } \\
\text { for students to develop } \\
\text { career life planning skills. }\end{array}$ & $\begin{array}{l}\text { k. In the UNM-LA career } \\
\text { class the students received } \\
\text { instruction on how to } \\
\text { develop career life planning } \\
\text { skills. }\end{array}$ & k. As intended \\
\hline $\begin{array}{l}\text { I. Include special attention } \\
\text { to building individual self- } \\
\text { confidence and } \\
\text { interpersonal skills. }\end{array}$ & $\begin{array}{l}\text { I. Special attention and } \\
\text { individual recognition is } \\
\text { provide is designed into the } \\
\text { program. The site visits are } \\
\text { one-to-one meetings so } \\
\text { that each student may feel } \\
\text { that they are receiving } \\
\text { individual attention. These } \\
\text { sessions also provide the } \\
\text { students with time to share } \\
\text { their accomplishments in } \\
\text { their lab. Completion of } \\
\text { the summer research } \\
\text { project provides an } \\
\text { opportunity to experience } \\
\text { success in a science } \\
\text { setting. }\end{array}$ & I. As intended \\
\hline
\end{tabular}




\begin{tabular}{||l|l|l||}
\hline $\begin{array}{l}\text { m. Include assessment of } \\
\text { students' work for the } \\
\text { purpose of giving them } \\
\text { feedback on the quality of } \\
\text { their work and improving } \\
\text { program activities. }\end{array}$ & $\begin{array}{l}\text { m. Assessment } \\
\text { opportunities are provided } \\
\text { at all phases of the summer } \\
\text { program. Student's daily } \\
\text { efforts are monitored by } \\
\text { the project staff and LANL } \\
\text { scientists. Students } \\
\text { present the results of their } \\
\text { research project in a } \\
\text { conference-like setting } \\
\text { astudents' work was } \\
\text { assed mentors, } \\
\text { made a final presentation } \\
\text { to their peers on their } \\
\text { project and took criticism } \\
\text { well. Students reports } \\
\text { were reviewed with the } \\
\text { students and suggestions } \\
\text { and comments were } \\
\text { provided. }\end{array}$ \\
& $\begin{array}{l}\text { students are allowed and } \\
\text { encouraged to critique and } \\
\text { ask questions. Acedemic } \\
\text { progress is monitored by } \\
\text { the UNM-LA staff during } \\
\text { the students classtime. } \\
\text { The students also are } \\
\text { video-taped while } \\
\text { presenting their research. } \\
\text { The video is then used as a } \\
\text { tool to polish the students } \\
\text { oral communication skills. }\end{array}$ & \\
\hline
\end{tabular}

5. Unique Contribution of DOE Laboratories

\begin{tabular}{||l|l|l|}
\hline COMPONENTS COLUMN & INTENDED COLUMN & ACTUAL COLUMN \\
\hline
\end{tabular}




\begin{tabular}{|c|c|c|}
\hline $\begin{array}{l}\text { a. Scientists, engineers, } \\
\text { and technicians: } \\
\text { * particpate in program } \\
\text { design and } \\
\text { implementation } \\
\text { * assist in developing } \\
\text { scientific/technical } \\
\text { content } \\
\text { work with students to } \\
\text { solve real/simulated } \\
\text { problems } \\
\text { serve as role models }\end{array}$ & $\begin{array}{l}\text { a. LANL staff: } \\
\text { * } \text { contribute to the } \\
\text { design of the students } \\
\text { research experience. } \\
\text { * present several } \\
\text { sessions during the } \\
\text { Project SEED program. } \\
\text { * provide access to and } \\
\text { assistance in using the } \\
\text { equipment and } \\
\text { instruments in their lab. } \\
\text { demonstrate the inter- } \\
\text { disciplanary and team- } \\
\text { effort approach to } \\
\text { research. } \\
\text { provide field trips that } \\
\text { provide participants } \\
\text { with an awareness of } \\
\text { some of the research } \\
\text { currently being } \\
\text { investigated at LANL. } \\
\text { continue to act as } \\
\text { mentors and contacts } \\
\text { for the Project SEED } \\
\text { students. }\end{array}$ & $\begin{array}{l}\text { a. Students really enjoyed } \\
\text { the tours as stated in their } \\
\text { post-surveys. They } \\
\text { appreciated the } \\
\text { introduction to the } \\
\text { resources available to them } \\
\text { during their summer } \\
\text { experience. Students } \\
\text { continue to keep in contact } \\
\text { with their mentors for --- } \\
\text { assistence in school } \\
\text { projects as well as help on } \\
\text { future presentations of } \\
\text { their research experience } \\
\text { such as their poster } \\
\text { presentations in } \\
\text { Washington, D.C. }\end{array}$ \\
\hline $\begin{array}{l}\text { b. Scientific/technical } \\
\text { facilities and equipment are } \\
\text { used for training, } \\
\text { immersion, and science } \\
\text { experiences. }\end{array}$ & $\begin{array}{l}\text { b. LANL and UNM-LA } \\
\text { facilities and technical } \\
\text { assisitance (along with the } \\
\text { necessary training) are } \\
\text { available to the students } \\
\text { during their summer } \\
\text { research experience. }\end{array}$ & b. As intended \\
\hline $\begin{array}{l}\text { c. Students activities } \\
\text { relate to the Lab's mission, } \\
\text { unique capabilities, and } \\
\text { core competencies. }\end{array}$ & $\begin{array}{l}\text { c. All of the students } \\
\text { research experiences and } \\
\text { tours are related to the } \\
\text { Lab's unique capabilities } \\
\text { and core competencies, as } \\
\text { we depend on Lab } \\
\text { personnel to provide } \\
\text {. infromation and activities }\end{array}$ & c. As intended \\
\hline
\end{tabular}

6. Follow-up 


\begin{tabular}{|c|c|c|}
\hline $\begin{array}{l}\text { a. Mechanisms such as } \\
\text { newsletters and electronic } \\
\text { mail enable } \\
\text { communications between } \\
\text { students and between } \\
\text { students and lab } \\
\text { scientists/technicians; } \\
\text { students continue to have } \\
\text { access to resources and } \\
\text { information of the Lab. }\end{array}$ & $\begin{array}{l}\text { a. No formal follow-up } \\
\text { mechanism is intended, } \\
\text { however, students are } \\
\text { encouraged to continue } \\
\text { contacts with Laboratory } \\
\text { staff, especially their } \\
\text { mentors. All presentors } \\
\text { and tour guides agreed to } \\
\text { serve as contacts and gave } \\
\text { out their numbers. }\end{array}$ & $\begin{array}{l}\text { a. Students have } \\
\text { continued to be in contact } \\
\text { with their mentors for help } \\
\text { on school science projects } \\
\text { as well as help on } \\
\text { presenting their research } \\
\text { experience at the ACS } \\
\text { national convention in } \\
\text { Washington, D.C. }\end{array}$ \\
\hline $\begin{array}{l}\text { b. Lab gives students } \\
\text { appropriate recognition } \\
\text { (e.g., ceremony, awards, } \\
\text { T-shirts); Lab encourages } \\
\text { recognition by school and } \\
\text { district (e.g., press } \\
\text { releases, ceremony) }\end{array}$ & $\begin{array}{l}\text { b. A reception and poster } \\
\text { session was planned for } \\
\text { the final week of the } \\
\text { program and family } \\
\text { members, mentors, } \\
\text { presenters, and Science } \\
\text { Education \& Outreach staff } \\
\text { were invited to attend. At } \\
\text { the reception certificates of } \\
\text { achievement were awarded } \\
\text { by the director of Human } \\
\text { Resources Division at the } \\
\text { Los Alamos National } \\
\text { Laboratory. A press } \\
\text { release was sent and } \\
\text { published in the LANL } \\
\text { Newsbulletin as well as the } \\
\text { local newspapers of the } \\
\text { Project SEED students who } \\
\text { particiapted in the Sci-Mix } \\
\text { poster session at the ACS } \\
\text { national convention in } \\
\text { Washington, D.C. }\end{array}$ & $\begin{array}{l}\text { b. Students stated that the } \\
\text { reception and poster } \\
\text { session was a highlight of } \\
\text { the Project SEED summer } \\
\text { program. The students } \\
\text { who went to Washington } \\
\text { enjoyed the recognition } \\
\text { they received from the } \\
\text { press release on their } \\
\text { accomplishments. }\end{array}$ \\
\hline $\begin{array}{l}\text { c. Lab provides advice, } \\
\text { support, and } \\
\text { encouragement for } \\
\text { students to share lab } \\
\text { experience with others and } \\
\text { assume leadership roles } \\
\text { (e.g., through tutoring, } \\
\text { presentations) }\end{array}$ & $\begin{array}{l}\text { C. The Science Education } \\
\text { \& Outreach group of the } \\
\text { Los Alamos National } \\
\text { Laboratory and the North } \\
\text { Central Section of the } \\
\text { American Chemical Society } \\
\text { supported Project SEED } \\
\text { students to go to } \\
\text { washington and present } \\
\text { their research experience at } \\
\text { the Sci-Mix poster session } \\
\text { at the ACS national } \\
\text { convention in Washington, } \\
\text { D.C. }\end{array}$ & c. As intended \\
\hline
\end{tabular}




\begin{tabular}{||l|l|l||}
\hline $\begin{array}{l}\text { d. Lab maintains } \\
\text { commitment, contact, and } \\
\text { support to students to } \\
\text { provide them information } \\
\text { on additional opportunities } \\
\text { and encourage them to } \\
\text { pursue and/or consider } \\
\text { science and engineering } \\
\text { careers }\end{array}$ & $\begin{array}{l}\text { d. Students will be } \\
\text { informed of any up-coming } \\
\text { events where they can } \\
\text { present their research } \\
\text { experience. Information on } \\
\text { future programs and career } \\
\text { information is sent to the } \\
\text { students. }\end{array}$ & $\begin{array}{l}\text { d. Students have } \\
\text { requested and received } \\
\text { information on ACS } \\
\text { financial aid. One student } \\
\text { has been accepted to } \\
\text { participate in a coop } \\
\text { program for high school } \\
\text { students. }\end{array}$ \\
\hline $\begin{array}{l}\text { e. Students maintain } \\
\text { commitment, contact, and } \\
\text { will support future program } \\
\text { participants }\end{array}$ & $\begin{array}{l}\text { e. All Project SEED I } \\
\text { students expressed an } \\
\text { interest and returning as } \\
\text { Project SEED II students } \\
\text { and will provide leadership } \\
\text { and support to the new } \\
\text { Project SEED I students. }\end{array}$ & e. As intended \\
\hline
\end{tabular}

7. Program Administration:

\begin{tabular}{||l|l|l||}
\hline COMPONENTS COLUMN & \multicolumn{1}{|c|}{ INTENDED COLUMN } & ACTUAL COLUMN \\
\hline $\begin{array}{l}\text { a. Is clearly assigned as } \\
\text { the responsibility of one or } \\
\text { more persons. }\end{array}$ & $\begin{array}{l}\text { a. Daily coordination and } \\
\text { responsibility is assigned to } \\
\text { one person, Joseph L. Vigil. } \\
\text { The person in charge of } \\
\text { program oversight and } \\
\text { authorization of LANL } \\
\text { commitment to the } \\
\text { program is Sharon Dogruel. } \\
\text { The person in charge of the } \\
\text { ACS management of the } \\
\text { Project SEED program is } \\
\text { Christine Brenan. }\end{array}$ & as intended \\
\hline $\begin{array}{l}\text { b. Involves parents as } \\
\text { much as possible and in as } \\
\text { many ways as appropriate. }\end{array}$ & $\begin{array}{l}\text { b. Parents and family were } \\
\text { invited to a mid-summer } \\
\text { BBO and end of the } \\
\text { summer closing ceremony } \\
\text { and poster session. }\end{array}$ & $\begin{array}{l}\text { younger brothers and } \\
\text { yolsters attended the } \\
\text { closing ceremony and } \\
\text { poster session where they } \\
\text { were thanked for their } \\
\text { attendance by the director } \\
\text { of Human Resources at the } \\
\text { Los Alamos National } \\
\text { Laboratory, Francis }\end{array}$ \\
Menlove.
\end{tabular}




\begin{tabular}{||l|l|l||}
\hline $\begin{array}{l}\text { c. Communicates with and } \\
\text { reports regularly to DOE } \\
\text { Headquarters }\end{array}$ & $\begin{array}{l}\text { C. DOE is regularly udated } \\
\text { through the annual project } \\
\text { review meeting and } \\
\text { through the evaluation and } \\
\text { quarterly reports. }\end{array}$ & c. As intended. \\
\hline $\begin{array}{l}\text { d. Maintains database of } \\
\text { applicant and particiapant } \\
\text { information }\end{array}$ & $\begin{array}{l}\text { d. a list of applicant and } \\
\text { particiapnt information was } \\
\text { compiled by the program } \\
\text { coordinator. This list will } \\
\text { be incorporated into the } \\
\text { group database by another } \\
\text { individual. }\end{array}$ & d. as intended \\
\hline
\end{tabular}

8. Program Evaluation:

\begin{tabular}{|c|c|c|}
\hline COMPONENTS COLUMN & INTENDED COLUMN & ACTUAL COLUMN \\
\hline $\begin{array}{l}\text { a. Monitoring occurs during } \\
\text { program }\end{array}$ & $\begin{array}{l}\text { a. Weekly Project SEED } \\
\text { information sheets where } \\
\text { filled out by the students } \\
\text { asking them to list any } \\
\text { highlights that they } \\
\text { experienced over the past } \\
\text { week, list any problems or } \\
\text { frustration that the } \\
\text { students experience over } \\
\text { the past week, and any } \\
\text { comments or suggestions } \\
\text { they may have. Mentors } \\
\text { and students provide } \\
\text { feedback and is a major } \\
\text { source of program } \\
\text { monitoring through site } \\
\text { visits conducted through } \\
\text { the summer. }\end{array}$ & a. As intended. \\
\hline $\begin{array}{l}\text { b. Students and mentors } \\
\text { have the opportunities to } \\
\text { provide feedback and input } \\
\text { during and after the } \\
\text { experience. }\end{array}$ & $\begin{array}{l}\text { b. As stated above in a. } \\
\text { Both the mentors and } \\
\text { students fill out a post- } \\
\text { program survey. }\end{array}$ & b. As intended \\
\hline $\begin{array}{l}\text { c. Pre- and post- program } \\
\text { assessments gather } \\
\text { information about impact } \\
\text { on students. }\end{array}$ & $\begin{array}{l}\text { c. Students completed } \\
\text { both a pre- and post- } \\
\text { program survey. }\end{array}$ & c. as intended \\
\hline
\end{tabular}




\begin{tabular}{||l|l|l||}
\hline $\begin{array}{l}\text { d. Program administrators } \\
\text { use evaluation to make } \\
\text { changes. }\end{array}$ & $\begin{array}{l}\text { d. The program } \\
\text { coordinator used } \\
\text { information gathered from } \\
\text { pre- and post-program } \\
\text { particiapnt surveys and } \\
\text { mentor surveys to make } \\
\text { recommendations for future } \\
\text { program changes }\end{array}$ & $\begin{array}{l}\text { d. Recommendations are } \\
\text { listed in the Program } \\
\text { Report. }\end{array}$ \\
\hline
\end{tabular}




\title{
U.S. DEPARTMENT OF ENERGY AMERICAN CHEMICAL SOCIETY \\ Los Alamos National Laboratory
}

\section{PROJECT SEED II PROGRAM}

PARTICIPANTS: High school juniors and seniors from northern New Mexico .

ENROLLMENT: Open to students from economically disadvantaged families.

Applications are available to high school juniors and seniors from school guidance offices in the spring.

Students must have completed one year of chemistry by the beginning of the program.

DURATION: $\quad 40 \mathrm{hrs} / \mathrm{wk}$ (June 6 to August 5,1994 )

LOCATION: Los Alamos National Laboratory. All participants are expected to provide their own transportation each day of the program.

COMPENSATION: Students receive a $\$ 1700$ stipend. Students will have an opportunity to earn both high school and college credit under the concurrent enrollment agreement set up by the University of New Mexico, Los Alamos and participating area high schools.

PHILOSOPHY: Project SEED offers qualified students meaningful scientific activities under the supervision of Laboratory research staff. The primary objectives are:

a. to encourage participants to pursue strong academic programs and to more fully develop their career potential;

b. to prepare participants for entrance into professional careers by providing students with work experience within a professional setting;

c. to encourage a more serious consideration of scientific careers;

d. to enhance each participant's self-confidence and ability to work effectively with research equipment, concepts, and scientific professionals.

Participants spend 80 percent of their time with a mentor, and 20 percent of their time participating in special activities including seminars and workshops in problem solving and critical thinking, college financial aid and career counseling, and technical communications. In addition, students participate in site tours to learn about basic research at the Laboratory, and present a paper and poster on their research.

For more information contact:

\author{
Joseph L. Vigil \\ Project SEED Coordinator \\ Los Alamos National Laboratory, P278 \\ Los Alamos, NM 87545 \\ (505) 667-1919
}




\section{PROJECT SEED}

sponsored by

The American Chemical Society and Los Alamos National Laboratory

Program Guidelines

\section{EINANCIAL GUIDELINES}

1. The student must be recognized as economically disadvantaged. Preference is given to students whose families have annual incomes that are below the federal poverty income guidelines * and who may be encouraged by their work in a chemical laboratory to make better use of their capabilities. An economically disadvantaged student applicant who is physically disabled must be considered on the same basis as any other applicant and not be discriminated against in any way.

"Federal poverty income guidelines from the 1993 Federal Register, Vol. 58, No. 28, February 12, 1993.

Size of family unit Income guideline

\section{$\begin{array}{ccccc}1 & 2 & 3 & 4 & 5 \\ \$ 6,970 & \$ 9,430 & \$ 11,890 & \$ 14,350 & \$ 16,810\end{array}$}

For families of more than five, add $\$ 2,460$ for each additional family member.

The maximum family income is $\$ 27,000$, except in cases where other factors are present which may deter a student from considering a career in science. The committee will accept applications from students whose family income is up to $\$ 34,000$ if evidence is provided that factors which contribute to underrepresentation in the sciences are present. Examples of such factors include:

d member of an underrepresented ethnic group (Black, Hispanic, Native American)

- parents/guardians have not attended college; or,

- student lives in a single parent household or is a member of a large family.

2. The student should be a commuting student.

3. Summer I students receive a minimum of $\$ 1,500$ for nine weeks of approximately 40 hours of research each week. Each Summer II student should receive a minimum of $\$ 1,700$ for no less than eight weeks of approximately 40 hours of research per week. 


\section{AMERICAN CHEMICAL SOCIETY \\ PROJECT SEED SUMMER II \\ 1994 \\ STUDENT RESEARCH DESCRIPTION}

RESEARCHER: Roger Tennant

TYPE OF RESEARCH: Analytical Chemistry

Measuring pressure buildup in storage drums using non-invasive techniques

\section{DESCRIPTION OF PROJECT:}

As a result of 50 years of work with radioactive materials, Los Alamos National Laboratory has thousands of drums containing waste of various types and compositions. Some of these drums produce gas as a result of chemical and radiation driven reactions. This project will explore techniques to measure pressure buildup in waste storage drums through non-invasive techniques. The two techniques that will be investigated involve deflection and acoustic based measurements.

\section{LEARNING OBJECTIVES:}

The student will be introduced to the state-of-the-art diagnostic equipment. The student will have the opportunity to gain a basic understanding of a complex measurement problem and become familiar with waste storage issues.

\section{TRAINING OPPORTUNITIES:}

The student will make extensive use of an acoustic analyzer, accelerometers, deflection measuring equipment, and personal computers. The student will receive training in environmentally conscious procedures and will be introduced to the process of using scientific and engineering principles to solve complex problems. 


\section{AMERICAN CHEMICAL SOCIETY \\ ProjeCt SEED $\cdot 94$ \\ Pre-Program Questionnalre}

This questionnalre has been designed to gather information that will help us evaluate and improve our program. Your answers w11l be anonymous, so you need not put your name on the questionnalre. Please feel free to answer the questions as honestly and thoughtfully as you can, and keep in mind there are no correct answers.

(Please circle only one answer code unless otherwise instructed.)

1. Sex:

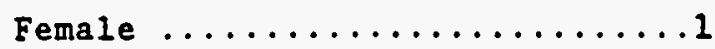

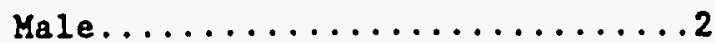

2. Race :

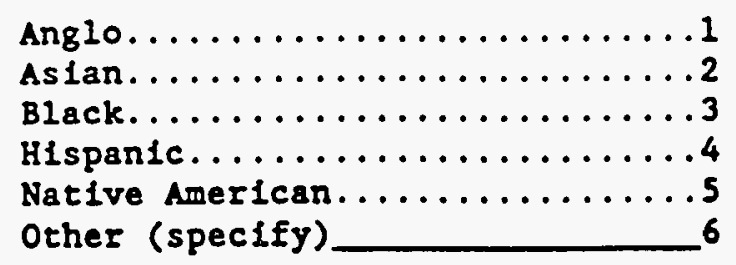

3. What do you expect to gain from the summer ACS Profect SEED program?

4. What plans do you have after high school graduation?

Attend college $\ldots \ldots \ldots \ldots \ldots \ldots \ldots \ldots \ldots \ldots$

Attend vocational/technical school.........

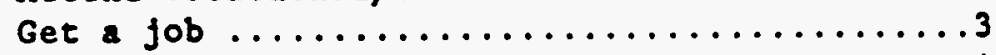

Other (please specify) $\ldots \ldots \ldots \ldots \ldots \ldots \ldots \ldots$

5. What type of career interests you most and why? 
6. Do you know any adults who are professlonals; that 1s, who have college degrees and are working in flelds that use the knowledge and training that degree provided?

Yes

No

7. What area of sclence do you most enjoy?

Within this area, what kinds of activitles do you enfoy doing?

8. How interested are you in the fleld of chemistry? (Please clrcle one response).

None

A 10 t

1

23

4

5

9. What do you know about the types of research currently going on at the Los Alamos National Laboratory? List the kinds of research topics.

10. What do you think it would be like working in a laboratory environment. 


\section{AMERICAN CHEMICAL SOCIETY \\ Project SEED 1994 \\ Post-program Questionnaire}

This questionnalre has been designed to gather information that will help us evaluate and 1mprove our program. Your answers will be anonymous, so you need not put your name on the questionnalre. Please feel free to answer the questions as honestly and thoughtfully as you can, and keep in mind that there are no correct answers.

(Please clrcle only one answer code unless otherwise instructed.)

1. Sex:

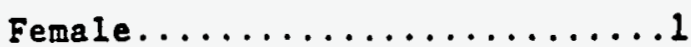

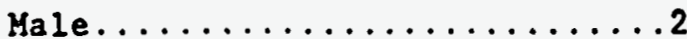

2. Race:

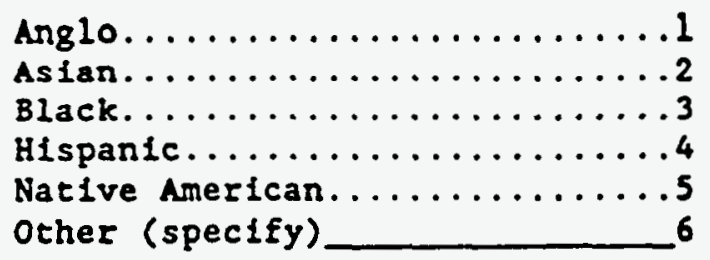

3. What, if anything, did you gain from this summer program?

4. What are your plans after high school graduation?

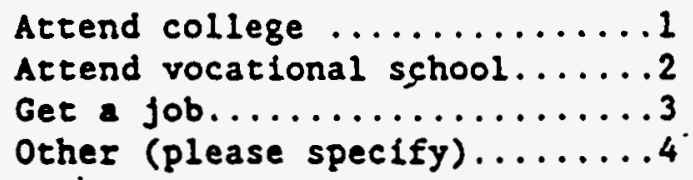

5. What type of career interests you most and why? 
6. What, if anything, did you gain working with your Laboratory mentor?

Did you work with anyone other than your Laboratory mentor?

$$
\text { yes }
$$

If yes, what did you gain?

7. What, if anything, did you gain from working at a Laboratory technical site?

8. Do you know any adults who are professionals; that 1s, who have college degrees and are working in fields that use the knowledge and training that degree provided?

Yes_ No

9. What area of science do you most enjoy?

Within this area, what kinds of activities do you enjoy doing?

10. How interested are you in the field of chemistry? (Please circle one response).

None

1
A Lot

4 
As the American Chernical Society's major commitment to social action, Project SEED was established in 1968 to help expand the career and educational outlook of high school students from families with incomes that meet financial program guidelines. The program is an innovative career development activity where students spend ten weeks during the summer in an academic, industrial or government research laboratory working under the supervision of a professional researcher. The primary objective of Project SEED is to encourage participants to pursue strong academic programs and to more fully develop their career potential.

The summer experience is designed to involve students in meaningful research supplemented with educational activities that include tours of selected Laboratory facilities, career and financial aid counseling for post-secondary training and oral and written communication skills development. Students prepare a technical, give presentations to their sponsoring groups and other students in the program and display a poster session.

This summer twelve high school juniors and seniors from schools throughout northern New Mexico have successfully completed the laboratory's fifth Project SEED session.

Individual mentors in MTL, CST, ESH, JCI, EES, and LS divisions guided and supervised the students in their introduction to research at Los Alamos.

(1)

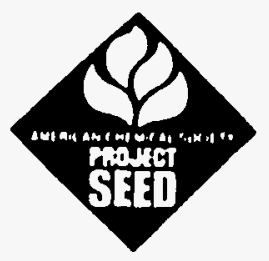

\section{AMERICAN CHEMICAL SOCIETY}

LOS ALAMOS NATIONAL LABORATORY

PROJECT SEED 1994

POSTER SESSION AND RECEPTION

TUESDAY, AUGUST 9 


\section{STUDENT}

Patrick Lopez

Lorenzo Lovato

Bryan Velasquez

\section{ACS PROJECT SEED}

\section{Anika Abdul-HaQQ}

Miguel Baca

Mathew Branch

Guillermo Caraveo

JoAnna Gallegos

Miguel Herrera

DeAnn Jaramillo

Albert Owen Jr.

\section{MENTOR}

Roger Tennant, CST-2

Ben Mattes, MTL-11

Phil Fresquez, ESH-8

Marke Talley, JCI

Stephen Kung, CST-10

John Davey, MTL-11

Mark Hoffbauer, CST-2

Jake Turin, EES-1

Jim Freyer, LS-1

George Busch, CST-6

Chuck Cotter, CST-10

\section{POSTER TITLE}

Non-Invasive Waste Drum Pressure Detection

Gas Seperation Using Electronically Conductive Polymers: A Study of Polyanaline

Monitoring Tritium Contamination with Honey Bees at Los Alamos National Lab.

Characterization of Streptococus from Frijoles Creek

Yucca Mountain: Sorption of Strontium

Conducting Polymers in Electrochemical Capacitors

Auto Correlation Measurement of a Sync Pumped Dye Laser System

Environmental Remediatin Using Gel Enhanced Water Permeable Chemically Reactive Barrier Systems

Growth of Rat Brain Tumor (9L) and Mouse Mammary Tumor (EMT-6) Cells

Los Alamos Visable Speckle

Yucca Mountain: A Natural Barrier for Strong Radioactive Waste 


\title{
U.S. DEPARTMENT OF ENERGY
}

\section{LOS ALAMOS NATIONAL LABORATORY}

AMERICAN CHEMICAL SOCIETY

\author{
PROJECT SEED \\ POSTER SESSION
}

TUESDAY, AUGUST 9, 1994 STUDY CENTER GALLERY

3:00 - 5:00 PM

REFRESHMENTS 


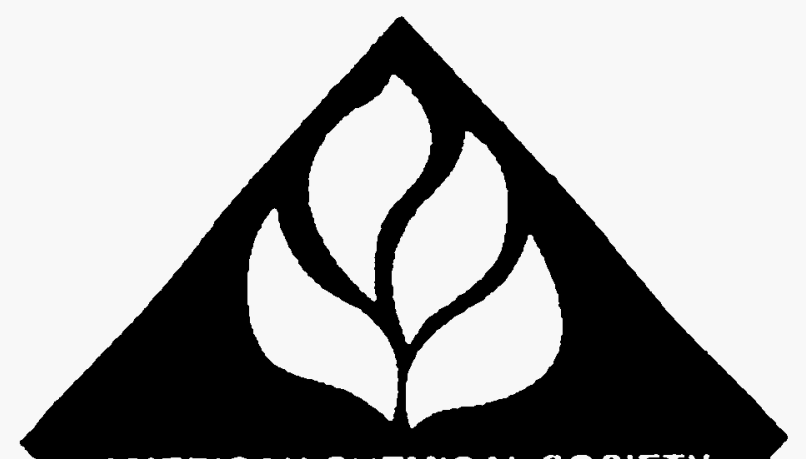

AMERICAN CHEMICAL SOCIETY

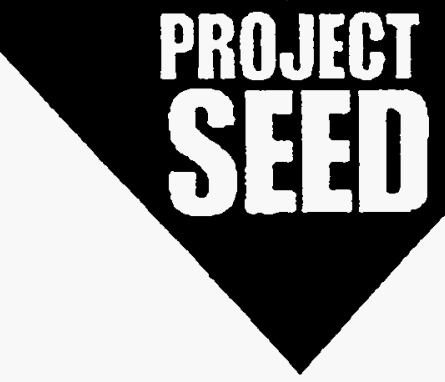

\section{Helping our youth} today

build a better tomorrow!

\section{Presenting the \\ 1994 Project SEED Students}

(Summer Educational Experience for the Disadvantage)

\section{Poster Session}

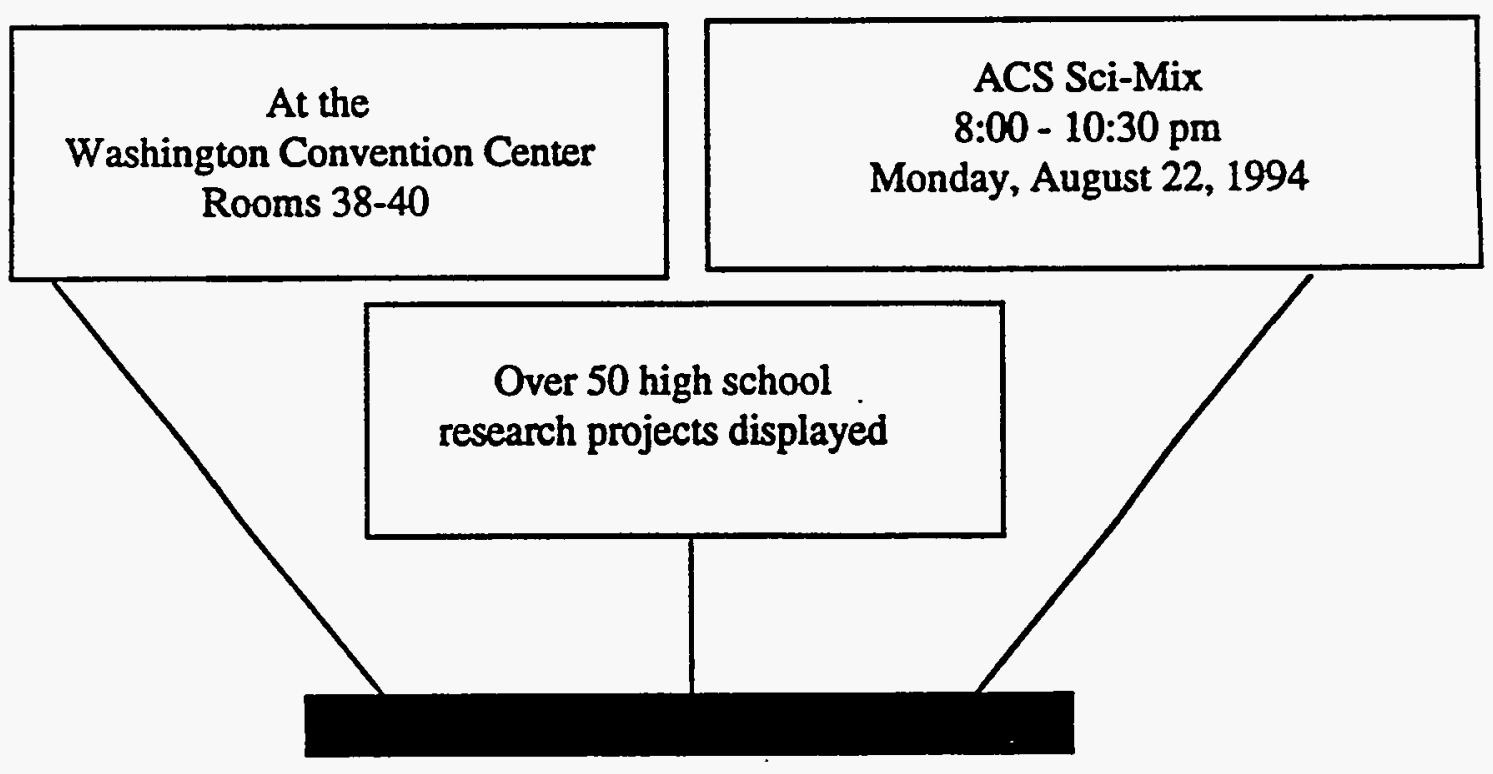


Remarks on Project SEED Trip to Washington DC

\author{
Patrick Lopez \\ Mentor: Roger A. Tennant \\ LANL CST-2
}




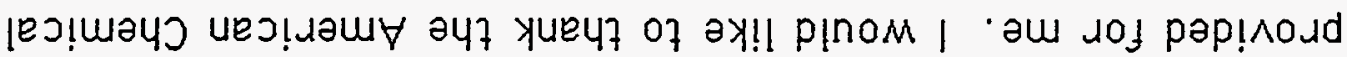

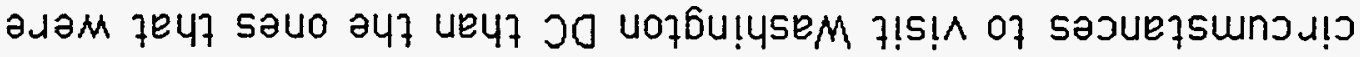

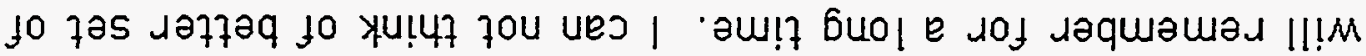

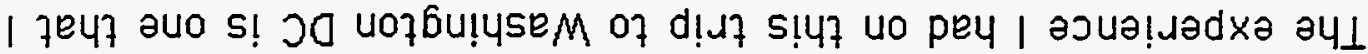

pinos I se hlybnodouz se suo!fsanb d!ay7

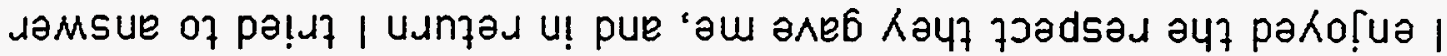
sourely s07 7e u! pafed!

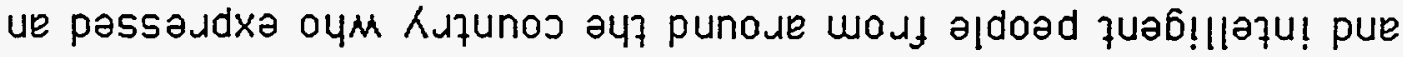

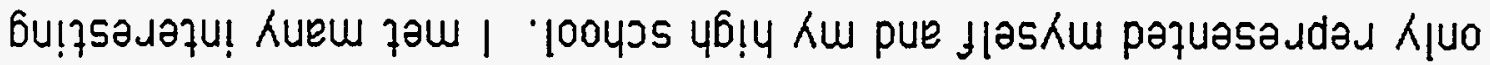

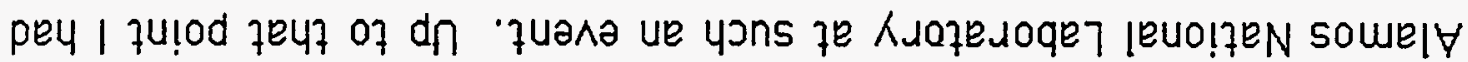

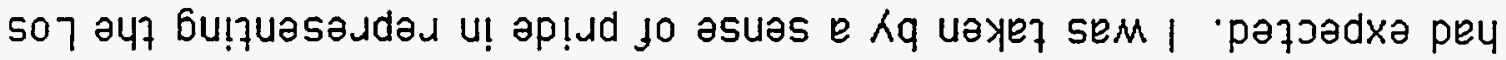

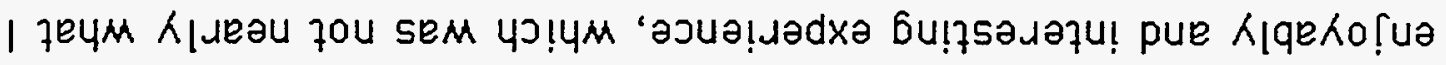
ue aq!nb aq of zno paudn

- 07 рәу!I ә^еч pInOM

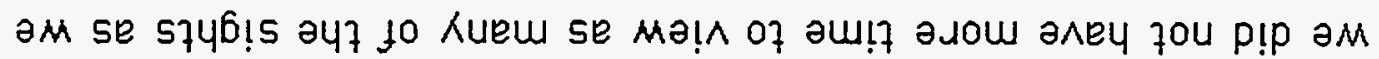

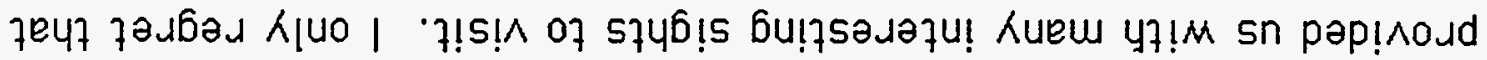

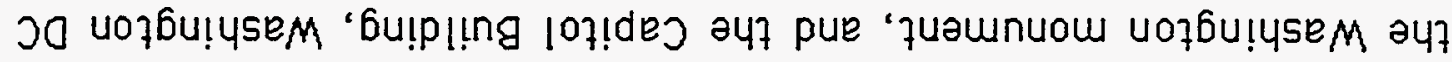

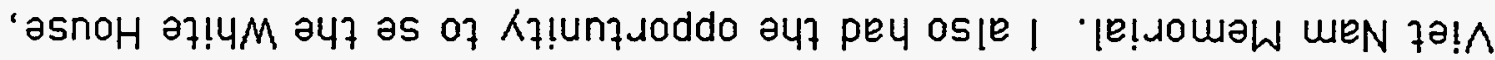

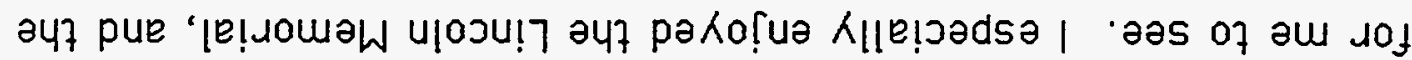

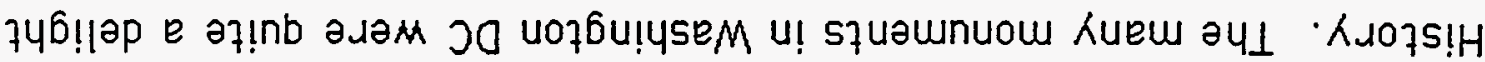

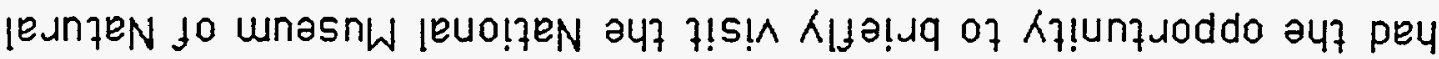

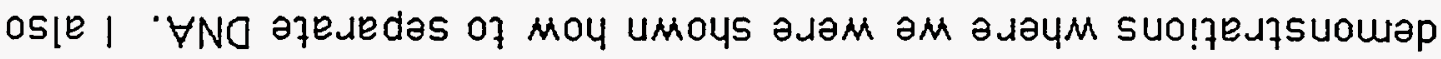

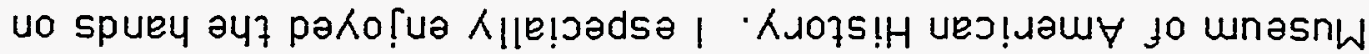

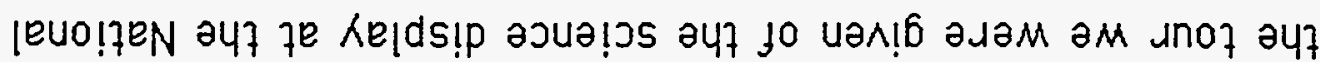

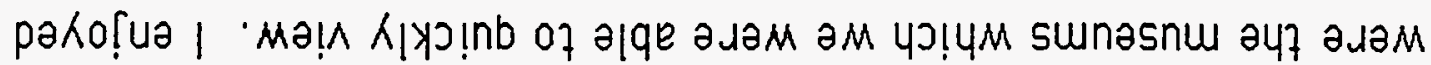

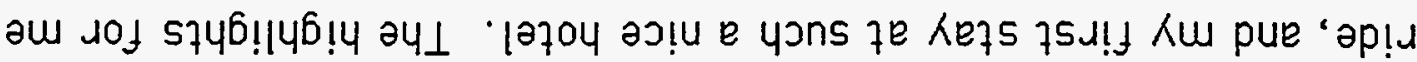

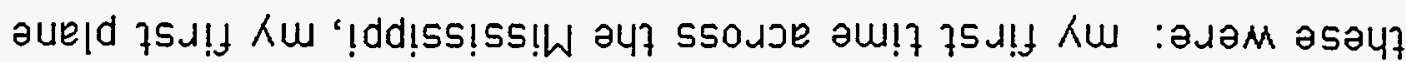

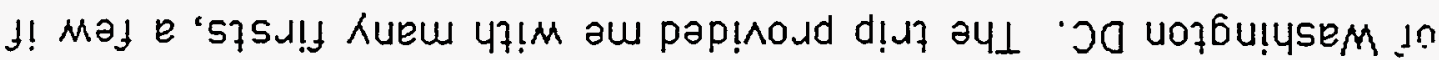
spunos pue pue słyb!s huem aył họua of am lof ajua!dadxa pue ał!nts

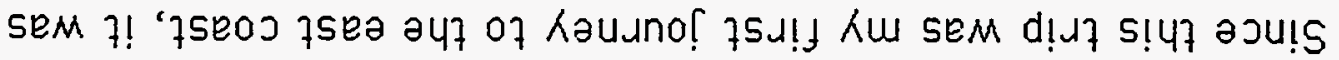
uo!jequasaud dajsod SJ

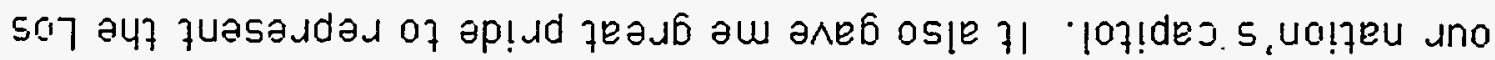

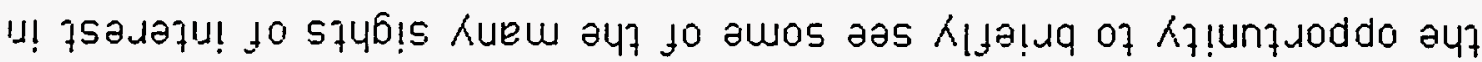

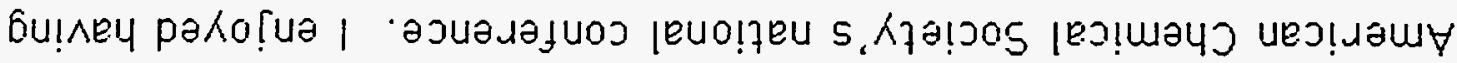

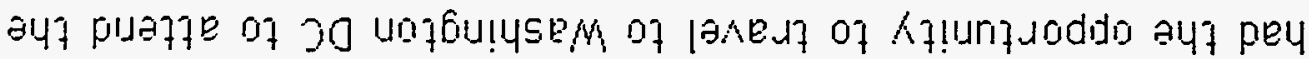

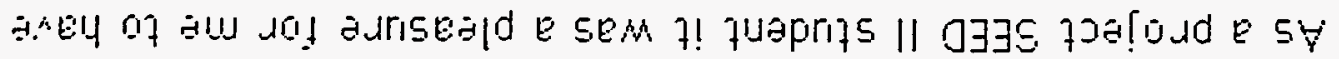


Society and Sience and Education Outreach first of all for allowirig me the opporturity to spend two summers with an excellent meritor. and secondly I would like to express my gratitude to ACS and SEO for sending me on this enjoyable trip. On a personal basis I would like to thank Sharon Dogruel and Joseph Vigil for the work they have done with Project SEED which, to me, has made it a huge success. 
August 25, 1994

Albert Owen, Jr. P.0. Box 224

Penasco, New Mexico

\section{3}

Seed Project

Los Alamos Laboratory

Los Alamos, New Mexico

To: The People that made this trip possible,

WASHINGTON, D.C.

Washington, D.C. was a great place to visit. I enjoyed it very much. This trip brought me many memories and lots of experiences. I really enjoyed seeing the beautiful monuments that Washington, D.C. has to offer. I want to go back there someday and experience what I did not get to see. I enjoyed staying at the Hotel which was the Hilton Tours. We had very nice rooms, and we were treated very good. The presentations went well, and from my opinion the Los Alamos posters were the best. After we finished the poster session, we enjoyed supper at a place called Planet Hollywood. We all had a great time.

I would like to thank everyone for the trip, and I can't express how much I enjoyed it. Thank you again. All the work and time that was put into this means a lot to me. I will always remember this trip. I realize that the "Seed Project" made this trip possible, and without it I would have never been able to go to Washington, D.C.

Sincerely,

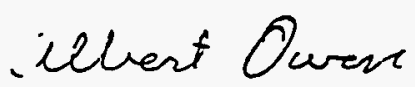

Albert Owen, Jr. 


\section{WASHINGTON REPORT}

Guillermo Caraveo

For: HR-SEO

September 1, 1994 
Phe recent visit to Washington D.C. was an enlightening and an infliential experience. The tour that the American Chemical Society supplemented to our group allowed us to apply our knowledge of science on several apparatus that were on display in tine Snithsonian Institute. Since I worked with lasers this summer, I was intrigued with the model that was set up to calculate the distance from the Earth to the moon using a He-Ne laser system. I also became aware of the techniques used to seperate DNA from a group of cells. I found some of the other displays to interesting such as the lowrider from Chimayo and several Indy cars. The poster session was a great success and I honestly believe that the four posters that we sent were the best looking and had the most intriguing topics. I had a chance to meet other students from different states; professors from Berkeley, Duke, and Notre Dame; scientists from Iiverpool and Oakridge laboratories. The poster session opened my eyes to the differences that science can make.

Besides having an educational experience, I found that there was a little bit of time to relax. Walking to the memorials was somewhat distant, yet somewhat near. It just seemed like everytime that I saw a memorial I saw a part of history. The swimming pool and hotel room were both very accomodating. Breakfast was always refreshing and the oderbs that were served in the evening were tasty. Planet Hollywood was definitely one of the highlights 
of the entire trip. Just looking at half of the movie props was like being in a movie itself.

In conclusion, I'd like to thank everybody who made this trip possible. Without the support that the HR-SEO group put out, I woulcin't be reflecting back upon the accomplishments that Project SEED gave me. I'd also like to give Joseph Vigil a special thanks. He was really a great coordinator and without his presence in Washington, I probably would have been bored. 


\section{Los Alamos \\ A national laboratomy \\ Los Alanos. Now Hexleo 87845 \\ public information group news release}

CONTAETS: James E. Rickoman, (505)667-7000

SEED STUDENTS GET NATIONAL SHOW-AND-TELL SESSION

LOS ALAMOS, N.M., Aug. 29, 1994 - Four students who participated this summer in a joint Los Alamos National Laboratory/American Chemical Society Sclence Education Ourreach program presentod posters outlining their research projects at a recent national meeting of the Americen Chemical Society.

Guillermo Caraveo, a senior at Española Valley High School, Patrick Lopez, a 1994 graduate of Peñasco High School, Lorenzo Lovato, a 1994 graduate of Española Valley Hligh School, and Albert Owen Ir., a senior at Perlasco High School, were chosen by the society to present aspects of their research at the Sai-Mix poster session last Monday in Washington, D.C.

The students honed their science skills this summer in Los Alamos as part of Project SEED, a program that provides economically disadvantaged high school juniors and seniors with meaningful scientific activities. As part of Project SEED, each student teamed up with a Laboratory mentor to do basic research.

Lopez and Lovato were back in Los Alamos this summer for their second round of the program to continue the research they had stared. Lopez again teamed up with mentor Roger Tennant, from the Laboracory's Chemical Science and Technology Division, to come up with a poster titled "Non-Invasive Waste Drum Pressure Detection."

Lovato paired up with Ben Mattes, of Los Alamos' Materials Science and Techno'ozy Division, for a poster tilled "Gas Separation Using Electronically Conductive Polymers. A Srady of Polyandine."

Project SEED newcomers Carrveo and Owen teamed up with Mark Hoffer and Cr:_is Cotter, from the Chemical Sctence and Technology Division. Caraveo's poster is titled "A L:o Correlation Measurement of a Sync Pumped Dye Laser System" and Owen's is titled "Y:_is Mountain: A Narural Barrier for Storing Radioactive Waste." 
The four students joined a myriad of professional researchers who presented posters at the session. Posters were viewed by hundreds of chemists amending the meeting.

"One of the neat things about the poster session was that a lot of the scientists attending would star walking to the SEED students about their posters without realizing that these students were still in high school or had just graduated," said Joe Vigil, Project SEED program coordinator for Los Alamos. "This was an exciting and valuable activity. Our SEED students had a good time and did a great job highlighting their research at the meeting."

In addition to the poster session, the student scientists toured the Science in American Lffo exhibit at the Smithsonian Museum of American History and visited the Hands-On Science Center, also at the Smithsonian.

Project SERD is a 10-week summer course in which students are inmersed in a professional technical environment that helps them develop a working knowledge of science research. SEED students spend four days a week with a mentor and receive supplementary classroom education.

"The mentors are the brekbone of this program," Vigil said. "They are very enthusiastic about giving students an ensiching experience, teaching them science and showing how science applies to their daily lives. The mentors also have helped sudents begin preparing for college even occasionally helping students apply for scholarships."

Project SEED students also have one day a week of classroom time where they leam "survival skills," Vigil said. They leam how to study, manage their time and budget their money. Students even get tips on keeping healthy, eating right and making sound carcer choices.

"We have $R$ lot of success stories that come out of this program." Vigil said. "We see kids going off to college and doing well, we see students coming back and working at the Laboratory es co-op studeats."

Stodents receive a \$1,700 stipend and can eam high school and college credits while in the program. Project SEED is sponsored by the Department of Energy, American Chemical Society and Los Alamos. 
Los Alamos National Laboratory is a multidisciplinary research organization that applies science and technology to problems of national security ranging from defense to energy research. It is operated by the University of Califomia for the U.S. Department of Energy. 
MS G740, LANL

American Chemical Society

Central New Mexico Section

Los Alamos, New Mexico 87544

September 2, 1994

Joe Vigil

Project SEED Program Coordinator

Science Education and Outreach

Human Resources Division

MS P278

Los Alamos National Laboratory

Los Alamos, New Mexico 87545

Dear Joe,

After your presentation today concerning the SEED student trips to Washington DC, the Central New Mexico Section of the ACS approved contributing an additional $\$ 800$ to the LANL program. We are happy to donate a total of $\$ 1600$ toward the trip on the condition that the students return a brief report to us regarding what they did during the trip and what value it may have had. This donation represents about $20 \%$ of our annual budget.

I wish to express my profound support for the SEED program and your participation in it. At the University of Akron I often directed student research during the summers. However, we had not budgetted anything for this purpose this year (or last) and need to know by November or December what your plans are for 1995. By planning in advance we can better inform you of what support we can offer, and tickets are much cheaper, too.

Let me also repeat my offer to contribute personally and professionally to your education outreach mission. I currently lead a show at the Children's Museum twice a year as well as participate in National Chemistry Week activities. I would be anxious to lead student research if clearances could be obtained for the students.

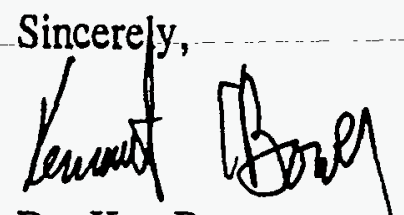

Dr. Ken Bower 
The American Chemical Society

\title{
DOE/Project SEED Program Oak Ridge National Lab
}

\author{
Summer '94 Session
}

Terry Lashley, Program Coordinator 


\section{REPORT ON PROJECT SEED \\ FOR THE AMERICAN CHEMICAL SOCIETY \\ Submitted by Manya J. Raman \\ August 19, 1994}

\section{OVERVIEW}

In its fifth year participating in the American Chemical Society Project SEED program, Oak Ridge National Laboratory (ORNL) hosted ten SEED I and five SEED II students. Of the SEED I students, eight came from Puerto Rico and two came from East Tennessee. Of the SEED II students, two came from Puerto Rico and three came from East Tennessee.

The ORNL program provides the students with first-hand research experience, college and career guidance, an opportunity to work with and learn from research scientists, and a chance to improve communication skills. The communication skills are especially important for the Puerto Rican students for whom English is a second language. This year the program was extended to include mathematics courses to complement students' research and an introduction to the internet. All the students were issued their own internet accounts.

\section{STUDENT SUPPORT}

Potential mentors were contacted and asked to submit project descriptions appropriate for high school students who had completed at least one year of chemistry. Seven different divisions were represented including: Metals and Ceramics, Biology, Analytical Chemistry, Environmental Science, Engineering Technology, Computing and Telecommunications, and Data Systems Research Development. Students were supervised both by individual laboratory mentors and a mathematics teacher who ran weekly seminars and visited the students in their laboratories throughout the program.

\section{SITE VISITS}

The mathematics teacher who supervised the students visited their laboratories throughout the eight week program. The SEED I students were visited three times. The purpose of the first visit, which took place at beginning of the second week, was to make sure that both students and mentors understood the expectations of the program and could communicate well with each other. The purpose of the second visit, which took place at the end of the fourth week, was for the supervisor to observe the student working on his or her project and to encourage students to begin outlining their paper. The purpose of the third visit, which took place at the beginning of the seventh week, was to 
make sure the projects were reaching an appropriate closure and to clarify requirements for the final paper and presentation.

The SEED II students were visited two times during the program, once at the beginning of the second week and once at the beginning of the seventh week. All of the returning students worked with the same mentor that they had worked with in SEED I, so they adjusted more rapidly than the SEED I students.

\section{EDUCATIONAL ACTIVITIES}

In addition to conducting research and participating in educational activities designed by the mentors, the students attended eight weekly three hour seminars to enrich their experience at ORNL (see schedule below). Three seminars were devoted to a course on statistics and included homework and outside readings. Three seminars featured scientists from ORNL who spoke about subjects of interest and educational value for the students. This year the topics were "Overcoming Obstacles to a Career in Science," "Navigating the Internet," and "Genetic Research and Ethics." Two workshops were added to the weekly schedule so students could learn how to prepare technical presentations and how to use their new internet accounts.

Students visited selected laboratory research facilities during the first week of the program. They learned about specific types of research conducted in each of the divisions they visited. They also toured the historic Graphite Reactor, learning about Oak Ridge's contributions to the Manhattan Project.

At the end of the program the students hosted a picnic for their mentors and the SEED staff. The Puerto Rican students provided food and activities to educate others about Puerto Rico.

\section{Schedule of Seminars and Activities}

June 27, $1994 \quad$ Orientation

June 29, $1994 \quad$ General Employee Training

July 1,1994 - Tour of Oak Ridge National Laboratory

June 30, $1994 \quad$ Seminar: Student introductions and discussion of initial impressions, survey for seminar talk topics, ice breaker activities 
July 7,1994

July 14, 1994

July 19, 1994

July 21, 1994

July 28, 1994

August 4, 1994

August 9, 1994

August 11, 1994

August 17, 1994

August 19, 1994
Seminar: Lecture on statistics-- Topic: Measures of center and spread

Manya Raman, mathematics teacher

Seminar: Lecture on statistics-- Topic: Types of distribution and $z$-values for the normal curve Manya Raman, mathematics teacher

Workshop: How to give oral and written scientific presentations

Linda Horton and Peter Tortorelli, Metals and Ceramics Division of ORNL

Seminar: Lecture on statistics-- Topic: Central limit theorem

Manya Raman, mathematics teacher

Seminar: Overcoming obstacles to a career in science Pat Scarbrough, Environmental Sciences Division of ORNL and SEED mentor

Seminar: Navigating the internet John Martellaro, Data Systems Research and Development

Keree Ivey, SEED II student

Workshop: Using e-mail, gopher, veronica, and the world wide web (students received their own accounts)

Robert Evridge, Consultant

Seminar: Genetic research and ethics Rick Woychick, Biology Division of ORNL

Student/Mentor Picnic

Paper editing session

Seminar: Final student presentations 


\title{
Xiomara W. Carrero Martinez \\ Environmental Sciences Division - GIS Lab \\ Project SEED 1994
}

\begin{abstract}
The University of Tennessee is working on a project that consists-of-growing switch grass to be used as fuel for power production. This is one of the efforts that nowadays are being performed to find cheaper and easier ways to produce electricity. But for really minimizing the costs it is needed to identify the croplands available and which would be best to grow the grass. In order to do this, the transportation modeling and agriculture economic staffs need to know where are the croplands and how far they are from the roads. The information needed for this analysis was created through a Geographic Information System (GIS). A GIS is a computer system that allows the analysis of spatial data. It is used for land management, espionage, military strategy, land use management, and emergency management. All GIS have similar capabilities, but what makes them different is the way they store and process the data. Therefore the purpose of this assignment was to create a point coverage and raster files for eleven states of the U.S. The raster files will be useful to determine the amount of croplands, while the point coverages will be used for the transportation modeling.

The first step for creating the raster files was to import the data to GRASS. Then, the data was converted to raster files. Finally the raster files were combined to create a new raster file with the following attributes: landcover, soil type, hydrologic units code and county fips code. From this combined raster file a statistical analysis was performed for the state of Missouri. The results of the analysis were that Missouri has $83342.31 \mathrm{~km}^{2}$ It was found that for some mapunits the amount of cropland was cero and for others it was as big as $90000 \mathrm{~km}^{2}$. After the statistical analysis was done, the combined raster files were used to create the point coverages were created in ARCINFO. These point coverages will be used by UT to do the transportation modeling and to evaluate the costs. The raster-files-will-be-used to calculate the cost per bushel aand the yield.
\end{abstract}




\title{
ENERGY DIFFERENCES BETWEEN ELECTRONIC ENERGY STATES OF THE URANIUM ATOM
}

\author{
Yolanda Figueroa Torres \\ Chemical and Analytical Sciences Division \\ oak Ridge National Laboratory \\ Oak Ridge, Tennessee 37831 \\ American Chemical Society \\ SEED Program 1994
}

\section{ABSTRACT}

The J. P. Desclaux Multiconfiguration Relativistic Dirac-Fock Program [2] has been used to perform the calculations of the energy differences between some electronic energy states of the uranium atom. In order to accelerate the process, only some energy states of the uranium III ion, with a positive charge of two, were calculated. Also, a library research has been made to find what calculations and measurements have been done before on the spectroscopy of uranium atom. only four experimentally determined energy differences of the uranium (2+) ion were found and these indicate that the lowest energy state of uranium $(2+)$ is an even parity state with a total angular momentum [1] of four (4). The calculations indicate that the ground state has odd parity. It can be concluded that only some of the calculated and experimental energy differences are in good agreement. 


\title{
DEATH TIME OF LETHAL MUTATIONS ON $a$ AND $p$ LOCI
}

\author{
E. D. Griffith*
}

Biology Division, Oak Ridge National Laboratory

Oak Ridge, TN 37830

*Project SEED Program, Summer I Participant

\section{ABSTRACT}

The time at which homozygotes die was determined for 3 mutations (general symbol $p l$ ) at the pink-eye $(p)$ locus and 3 mutations (general symbol $a l$ ) at the nonagouti (a) locus. In the stocks containing the $p$-locus, the $p \ell / p \times$ female was made pregnant by $p \ell / p \times$ (Experimental series) or by $p \times / p \times$ (Control Series) male. The same experimental and control series was carried out in the stocks containing the a-locus mutation. Uterine contents of the pregnant female were examined at 14.5 days, post conception. All together, 75 females were dissected and 681 corpora lutea (representing ovulations) counted. In two of the three $p$-locus mutant stocks, the embryos clearly die post implantation. The other $p$-locus mutant stock appears to die pre-implantation. In the $a$-locus mutant stocks, one of the three dies post implantation, one dies preimplantation, and one was inconclusive, due to imbalanced translocation segregants. 


\section{AIRCRAFT SHIELDING PROGRAM}

D.H. Harris

Engineering Technology Division. Oak Ridge National Laboratory

Oak Ridge, TN 37830

\section{ABSTRACT}

The Aircraft Shielding Program was a joint effort in conjunction with the AF Wright Laboratory and was supported by the FAA and the DOE. Eight tests were performed to determine: charge size, shield areal density, and charge condition.

Shielding panels were fabricated for the tests using commercially available materials . common to aircraft structures. The shielding panels were mounted on the inside walls of the B-52 aircraft used in these tests.

Two different charge sizes were used in these tests, as well as two different charge conditions. The explosives were mounted inside of the aircraft $122 \mathrm{~cm}$ from the surface of the shielding, and were detonated.

The conditions of the system components and the aircraft skin were used to evaluate the effectiveness of the shield panels. Visual examination of the shield panels showed how the individual layers were affected by the different explosions. 
Denny Hensley

\section{Program Management at the Office of Environmental Technology Development}

The Department of Energy (DOE) is committed to safely managing its wastes and cleaning up past environmental results. To develop improved technologies to accomplish these goals, DOE created the office of Technology Development within the Office of Environmental Restoration and Waste Management. This office provides the funding and approval on research projects. There is a strict guide as to how these projects are started. This paper will explain the levels of acceptance of a research project and the process by which a TTP (Technical Task Plan) is developed and approved or denied. This will also show some of the major accomplishments of the Oak Ridge National Laboratory staff in the fields of Environmental Technology Development. 
DEVELOPMENT OF INTERNET TECHNOLOGIES AND THE DSRD WEB SERVER

\author{
Kerry M. Ivey \\ student of John Martellaro \\ Data Systems Research and Development (DSRD), \\ Martin Marietta Energy Systems \\ Oak Ridge, TN 37830
}

Mentors: John and Lea Martellaro

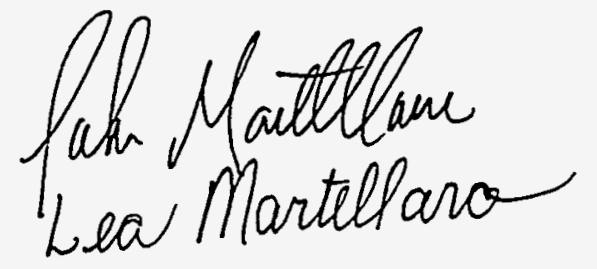




\section{ABSTRACT}

The research conducted included the investigation of the Internet: its design, importance, and capabilities and development of the Data Systems Research and Development (DSRD) World Wide Web server. 


\section{CONVERSION OF A VHS MOVIE INTO A MPEG MOVIE Mirta Paola Leon Arizmendi Office of Science Education and External Relations \\ Oak Ridge National Laboratory \\ Oak Ridge, Tennessee 37831 \\ American Chemical Society \\ Project SEED 1994}

\section{ABSTRACT}

The purpose of this research was to learn how to incorporate video materials produced by students in the Regional Science Center into the Oak Ridge NAtional Laboratory (ORNL) "homepages" in Mosaic for Science Education and External Relations. The materials used were a Panasonic videotape camera, a Videotape, a Radius Video Capture Board, a Macintosh II fx, Diva Videoshop Software, and Software Sparkle. The movie was changed into a Semi-Quick time format then into an actual Quick Time format, and finally it was converted into a Movie Picture Experts Group (MPEG movie). The Mpeg movie is available for anyone with access to mosaic to see it. 


\section{Effect Of Heat Treatment At $1150^{\circ} \mathrm{C}$ On Creep Rupture Properties of $\mathrm{A} \mathrm{Fe}_{3} \mathrm{Al}-\mathrm{Based}$ Alloy Yoalis Marrero-Claudette McKamey}

\section{ABSTRACT}

The iron aluminide alloys are recognized for their excellent corrosion resistance. This property is important for enabling their use for structural applications. These alloys also have poor creep resistance which is slow deformation over a period of time at constant temperature and stress. This research has the purpose of finding the temperature and stress conditions under which a chosen $\mathrm{Fe}_{3} \mathrm{HI}-\mathrm{based}$ alloy heat treated at $1150^{\circ} \mathrm{C}$ has the best creep resistance.

The effects of heat treatment at $1150^{\circ} \mathrm{C}$ on the creep-rupture properties of a $\mathrm{Fe}_{3} \mathrm{Al}$-based alloy were studied. Tests were conducted in air using various test temperatures and stresses in order to obtain creep activation energies and constants. The modes of failure were identified using optical metallography and scanning electron microscopy.

It can be concluded that the addition of $\mathrm{Mb}, \mathrm{Nb}, \mathrm{C}, \mathrm{Zr}$, and $\mathrm{B}$ helped in a fauorable way the improvement of the creep resistance of the FA-180 alloy. HIso, the creep rates obtained on the creep resistance almost equalizes the rates of the stainiess steel which were the expected results. The results also indicates that this alloy has a good creep resistance up to a temperature of $650^{\circ} \mathrm{C}$. 


\title{
MECHANICAL PROPERTIES OF OXIDIZED V-5Cr-5Ti
}

\author{
Cynthia E. Matos
}

\section{Abstract}

$\mathrm{V}-5 \mathrm{Cr}-5 \mathrm{Ti}$ has been chosen as the reference alloy for a proposed fusion reactor. It has been identified as the alloy with the most potential to attain the combine goals of high temperature capability and fabricability. These alloys offer the potential of higher heat loads and higher operating temperatures than steels. This research determined the relationship between oxygen content (bulk and oxide) and mechanical properties of the $\mathrm{V}-5 \mathrm{Cr}-5 \mathrm{Ti}$ alloy.

Results indicated that at each temperature and time there is a competition between oxygen diffusing into the material along the grain boundaries and the formation of surface oxide. A longer time at temperature allows more oxygen to diffuse in. The oxygen along the grain boundaries is the major player determining the elongation of the material.

During the $500^{\circ} \mathrm{C}$ anneal, there is an oportunity for the oxygen along the grain boundary to form discrete oxides. At $950^{\circ} \mathrm{C}$, the rate of the oxide formation is faster. 


\title{
ENERGY DIFFERENCES BETWEEN ELECTRONIC ENERGY STATES OF THE NEODYMIUM(2+) ION
}

\author{
Jorge 0 . Munoz \\ Chemical and Analytical Sciences Division \\ Oak Ridge National Laboratory \\ Oak Ridge, Tennessee 37831
}

\section{American Chemical Society \\ Project SEED 1994}

Abstract

Absolute values of the electronic energies, corresponding to the total angular momentum values from zero to eight for even and odd parity states of neodymium(2+) ion, have been calculated. The energies were calculated using the computer program of J.P. Desclaux(2). It appears that the program was used for the first time ever with more than one configuration in the study of neodymium(2t)-ion. The energies calculated present a ground electronic state with an even parity and a total angular momentum of four. - Electronic-energy differences were calculated-with respect to the ground state $(3)$ energy obtained. 


\section{THE GROUTING MIXED WASTE PROCESS}

Fernando J. Padilla-Rodriquez

Senior High School Emilio R. Delgado, Corozal

Research Paper for The SEED Program

Chemical Technology Division

August 19, 1994

Prepared by the

OAK RIDGE NATIONAL LABORATORY

Oak Ridge, Tennessee 37831

managed by

MARTIN MARIETTA ENERGY SYSTEMS under contract DE-AC05-640R21400 


\begin{abstract}
The Pollution Prevention and System Analysis Group has developed a tool called FLOW, which is a of computer that simulatores chemicals processes. FLOW is a Flow Sheet Maker, that is reason why the program was called FLOW. Another tool for analyze chemical process is the Pollution Prevention Opportunity Assessment (P2OA) Worksheets. The reason of the development of FLOW is that the mixed waste has always been a problem for the waste management. The objective of this research was to analyze the grouting mixed waste process using the P2OA Worksheets and FLOW. The methodology used consists in evaluating the grouting mixed waste process using two Pollution Prevention tools or methods. Those tools are the Pollution Prevention Opportunity Assessment work sheets and the FLOW. The results demonstrated that a simple, inexpensive and effective mixed waste treatment process is the best option for treating a mixed waste.
\end{abstract}




\section{ENVIRONMENTAL SAFETY AND HEALTH ASPECTS OF IRIDIUM PROCESSING IN THE OAK RIDGE NATIONAL LABORATORY METALS AND CERAMICS DIVISION \\ J. RODRIGUEZ* \\ METALS AND CERAMICS DIVISION, OAK RIDGE NATIONAL LABORATORY, OAK RIDGE, TN 37830 \\ *PROJECT SEED PARTICIPANT}

\section{ABSTRACT}

Iridium (Ir) is a metal that has unique mechanical properties. In a pure form and as a specialty alloy it exhibits great strength and resistance to heat and chemical attack. Ir is also very resilient and withstands impact. These properties make Ir the material of choice as the protective cover for the plutonium $(\mathrm{Pu})$ heat source used in "deep space" satellites. The Oak Ridge National Laboratory (ORNL) Metals and Ceramics (M\&C) Division prepares unique alloys of Ir for this purpose. M\&C prepares Ir metal blanks for the space program from Ir powder through a series of industrial processes that include metal compaction, drop-casting, extrusion, and hot rolling. The drop-cast Ir is placed in a molybdenum (Mo) cover. Following extrusion, the Mo cover must be removed using mixed acids. A combination of nitric and sulfuric acids are used to remove Mo. The removal process was the focus of this study. To better understand the hazards of this operation the process was observed and then reconstructed. Observations focused on personal safety aspects. Reconstructing the process was done to develop empirical data on the release of acid fumes and to recommend a procedure for the neutralization of acids. 


\title{
SEARCHING FOR AN OPTIMUM METHOD TO CONTAIN VOLATILE ORGANIC COMPOUNDS
}

\author{
Inda M. Rodriguez \\ Environmental Science Division \\ Oak Ridge National Laboratory
}

\section{ABSTRACT}

Containerization is a way of designing something that will contain volatiles so the gaseous phases cannot escape from the vial. It requires three components; vial, cap, and septa, but in this research, the main concern was focused on septa. Three experiments were done to get into concrete conclusions about which septum is the best, these are; the Methanol Immersion Procedure, The Gravimetric Study and the Inverted Gravimetric

Results obtained from this whole study have shown that the septum that best restricts Volatile Organic

Compounds. (VOC) from escaping the vial has to be a very well designed one. The septa that showed the lowest leakage was the Tekmar adapter, it is made-up of; a vyton seal, a teflon ball and a steel adapter, but its disadvantage is that it can be used only once, then the studies showed that Eaglepicher, although its design is not like the Tek adapter, seems to be also a good choice for containerization, and it can be used more than once. 
NAME:Félix Josa Rosa González PLANT: $\mathrm{X}-10$

MENTOR: H. G. Karn Jr.
DIVISION: Motals \& Coramios

BUILDING: 4508 OFFICE: 249-C

\section{IITLE: IHE IMPORTANCE OF ACCURATE OR AS BUILT DRAWINGS TO THE RESEARCH ACTIVITIES OF THE OAK RIOGE NATIONAL LABORATORY.}

\section{I.ABSTRACT:}

This research is an example of how engineering can helps us in the daily work. The main purpose of this research is learning about reading and interpreting drawings, to learn how to field check existing drawings and to mark up the drawings so they will accurately show what exists in the field. With the architectural drawings, check if the building structure is exactly as it appears on the drawings. After have done the architectural drawings get the electrical drawings and field check for proper location and marking of the electric panels. With the building drawings put the electric panels in the correct place with the markings. Check with the electrical drawings and put on them the changes in the panels. After finishing, go to the drawings table and use the copies of the blue prints to up date or correct the old drawings the same way did the architectural drawings. With the blue prints marked up, put them with the other drawings and remove the out of date drawings and throw them away. Using the different drawings of the buildings can noticed that this research was necesary because the drawings did not have some changes. this research offers to many people new, and trusworthy information and drawings of each building. 


\section{Project SEED}

Sponsored by: The American Chemical-Society

Identifying Croplands Through the Use of a GIS

Jessica M. Taylor

August 19, 1994 
Abstract

Determining the Relationship Between Croplands

and Soil Types Through the use of a Geographic Information System

The University of Tennessee is working on a project which consists of determining possible locations to grow switch grass. This will be used as an alternate fuel source for electricity. To do this, the amount of croplands and which would be best to grow it on is needed.

To obtain this information a Geographic Information System (GIS) was used. A GIS is a computer system that allows the analysis of spatial data. All GIS have similar capabilities, but the way the store and output data is what makes them different.

The purpose of this project was to create raster files and a point coverage for 11 states of the U.S. The raster files allow one to determine the amount of cropland. The point coverage will be used for transportation modeling.

The first step is to import all obtained data into GRASS. Then the data must be converted from vector format into raster format and edited. Then attribute tables containing soils, land cover, county fips code, and hydrologic units code must be attached. After this the combined data with 
attributes are imported into $\mathrm{ARC} / \mathrm{INFO}$ to convert the coverage to a point coverage. The reason for the use of two GIS (GRASS and ARC/INFO) is that the output is different.

The states chosen to illustrate the results are Georgia and Missouri. It showed that Missouri had the most cropland. The results showed the total and average amount of cropland and the standard deviation. 


\section{SEED Project Final Presentations \\ August 19, 1994}

Note to mentors and students: Please do not leave without filling out an evaluation form!

\begin{tabular}{|c|c|c|}
\hline $8: 00-8: 15$ & Denley Hensley & $\begin{array}{l}\text { Program Management at the Office of } \\
\text { Environmental Technology }\end{array}$ \\
\hline $8: 15-8: 30$ & Emily Griffith & $\begin{array}{l}\text { Death Time of Lethal Mutations on } a \\
\text { and } p \text { Loci }\end{array}$ \\
\hline $8: 30-8: 45$ & $\begin{array}{r}\text { Yoalis Marrero-Santos } \\
\checkmark\end{array}$ & $\begin{array}{l}\text { The Effect of Heat Treatment on the } \\
\text { Mechanical Properties of } \mathrm{Fe}_{3} \mathrm{Al}\end{array}$ \\
\hline $8: 45-9: 00$ & Felix Rosa-Gonzalez & $\begin{array}{l}\text { Verification of Engineering Drawings } \\
\text { of Buildings at ORNL Metals and } \\
\text { Ceramics Division }\end{array}$ \\
\hline $9: 00-9: 15$ & Inda Rodriguez-Ramirez & $\begin{array}{l}\text { Evaluating Containerization of Volatile } \\
\text { Chemicals }\end{array}$ \\
\hline $9: 15-9: 30$ & $\begin{array}{l}\text { Joannie Rodriguez- } \\
\text { Berdecia }\end{array}$ & $\begin{array}{l}\text { Environmental Safety and Health in a } \\
\text { Research Lab }\end{array}$ \\
\hline $9: 30-9: 45$ & $\begin{array}{c}\text { Yolanda Figueroa-Torres } \\
\checkmark \\
\end{array}$ & Energy States of Uranium \\
\hline $9: 45-10: 00$ & Jorge Muñoz & Energy States of Neodymium \\
\hline $10: 00-10: 15$ & $--\bar{B}$ & $\mathrm{~A}$ \\
\hline $10: 15-10: 30$ & Paola Leon-Arizmendi & Making Movies for the Internet \\
\hline $10: 30-10: 45$ & $\begin{array}{l}\text { Fernando Padilla- } \\
\text { Rodriguez }\end{array}$ & $\begin{array}{l}\text { Pollution Prevention Technology } \\
\text { Development Studies }\end{array}$ \\
\hline $10: 45-11: 00$ & Kerry Ivey & $\begin{array}{l}\text { Surfing Cyberspace and Navigating } \\
\text { the Internet }\end{array}$ \\
\hline $11: 00-11: 15$ & $\begin{array}{l}\text { Jessica Taylor and } \\
\text { Xiomara Carrero- } \\
\text { Martinez }\end{array}$ & $\begin{array}{l}\text { Relationship Between Cropland and } \\
\text { Soil Type }\end{array}$ \\
\hline $11: 15-11: 30$ & Dustin Harris & $\begin{array}{l}\text { Shielding Aircraft Against Internal } \\
\text { Explosives }\end{array}$ \\
\hline $11: 30-11: 45$ & Cynthia Matos & Vandium Oxygen System \\
\hline $11: 45-12: 00$ & Manya Raman & $\begin{array}{l}\text { Evaluations and } \\
\text { Concluding Remarks }\end{array}$ \\
\hline
\end{tabular}




\section{American Chemical Society DOE/Project SEED Student Scholars Partnership}

\section{FINAL REPORT}

The American Chemical Society (ACS) ECUT- DOE/Project SEED Student Scholars Partnership supported 100 high-potential, economically disadvantaged, high schools students in a comprehensive summer research experience at Los Alamos National Laboratory (LANL) in New Mexico and Oak Ridge National Laboratory (ORNL) in Tennessee from 1990-1994.

\section{About Project SEED:}

The program was run in cooperation with ACS Project SEED (Summer Educational Experience for the Economically Disadvantaged), a program which places economically disadvantaged students in research laboratories for eight-toten weeks of the summer. The students work on a research project under the direct supervision of a scientist and currently receive an educational award of $\$ 1,500$. More then 4,000 students have participated in Project SEED since the program's inception in 1968.

In 1992, Project SEED expanded its program to include a second summer of research through the Project SEED Summer $\Pi$ program. This program, begun with a generous grant from the Bader family, has allowed approximately 200 students to return for an additional summer of research. Summer II students currently receive a $\$ 1700$ educational award and are also eligible for a travel grant of up to $\$ 100$ to present their research at a scientific meeting.

The Project SEED College Scholarship program began in 1993 with three scholarships awarded to outstanding and deserving SEED alumni for use at colleges of their choice. The Committee on Project SEED selects students based on an application which contains a personal statement of career goals and letters of reference from a high school science teacher and the student's SEED preceptor. The scholarships are meant to encourage the students to pursue studies in science and to help them in their transition from high school to college. Five oneyear, non-renewable scholarships will be awarded in 1995. 
Although Project SEED is not specifically a minority program, many participants are from minority groups underrepresented in science $(68 \%)$, and a large percentage $(60 \%)$ are female.

\section{Project Goals and Objectives:}

The primary objectives of the ECUT-DOE/Project SEED Student Scholars Partnership, as stated in the original proposal, were :

- to encourage economically disadvantaged American students to enter scientific careers.

- to provide a comprehensive experience in scientific research that will involve them in scientific methods and a personal relationship with a mentor/researcher.

The grant was to support 100 high-potential, economically disadvantaged, minority high school students to do research at Department of Energy ECUT labs and their affiliated institutions.

\section{Project Outcome:}

The ECUT-DOE/Project SEED Student Scholars Partnership supported 100 students over five years at LANL and ORNL. With a large program structure in place, the laboratories were able to host an additional 29 SEED students with funding from ACS and the laboratories themselves. Of these students, 21 were participants in the SEED Summer $\Pi$ program. The experience has been positive for the laboratories themselves as each one expects to host a large number of students in 1995 (Oak Ridge, 23; Los Alamos, 12) through the regular Project SEED program.

Participants in the DOE/Project SEED partnership were primarily underrepresented minorities (83\%) with $77 \%$ of the students being of Hispanic origin. The program had approximately $60 \%$ female participants. The attached table provides a breakdown of the gender and ethnic backgrounds for each site and each year.

The LANL program recruited students from area high schools in New Mexico. These students commuted to the laboratory daily. 
The students participating in the ORNL program were primarily from Puerto Rico and recruited from the Causa program. This program, similar to Upward Bound, encourages Puerto Rican students starting in the eighth grade through college to study math and science through a series of extracurricular activities. ORNL provided them with local housing, a food allowance, transportation to the laboratory, and residential teachers. Students paid for their own travel to Tennessee.

The students at both sites worked eight-to-nine weeks during the summer with a preceptor (mentor) on a research project, generally of chemical nature. The students attended classes regularly on improving math skills, critical thinking, keeping of a laboratory notebook, and scientific writing. In addition, the students went on field trips to area laboratory facilities and universities. They discussed educational and career options and received instruction on the process of selecting and applying to a college program. All the students wrote a full report on their research at the conclusion of their research.

At the end of each summer, the student at both sites presented their research either orally or in a poster format to other scientists, students, and, in some cases, their parents. Time was spent during the program preparing the students for these presentations, sharpening both their writing and speaking skills. Five students from Los Alamos traveled to fall ACS national meetings. At these meetings, they presented their research at Sci-Mix, a large interdisciplinary poster session which several hundred scientists attend. Comments from students indicated that presenting their research at these meetings served to strengthen their self-confidence.

Two students who have participated in the ECUT-DOE/Project SEED Student Scholars Partnership have received Project SEED Bayer Corp. College Scholarships. David Chavez of Rancho de Taos, New Mexico was awarded one of these scholarships in 1993. He did research at LANL in 1990 and 1992 and is now majoring in chemistry at California Institute of Technology. Jorge Muñoz of San Lorenzo, Puerto Rico did his research in 1994 at ORNL and was selected to receive a 1995 scholarship. He plans to pursue an advanced degree in physical chemistry. 
Each student completed a pre- and post-program survey, required of all Project SEED students. These surveys provided information on the short-term impacts of the program. In addition, the LANL program used their own survey -instrument-with-their-students-Both-surveys-indicated-that the-studentsenjoyed the summer and learned a great deal about research. Many felt they gained expertise and self-confidence in the laboratory and have been encouraged to pursue further study in the sciences.

Due to the high mobility of low-income families, Project SEED staff have been unsuccessful with the long-term tracking of students. Attempts in conducting a longitudinal study have been unsuccessful. The return rate on the surveys was quite low (10\% or less). As a result, the ACS has contracted an independent evaluating group, PS International of Annapolis, MD, to conduct a comprehensive study of Project SEED. This group will perform an extensive search of students who have participated in the SEED program since 1968 and will attempt to determine the impacts the program has had on the lives of these students. In addition, the evaluation will look at the effectiveness of different programs including those at the DOE sites. The students who participated in the DOE/Project SEED partnership will be compared to the general SEED population. The report will be available in late 1996.

In spite of the lack of quantitative data, it appears that the ECUTDOE/Project SEED Student Scholars Partnership was successful in encouraging students to pursue studies in science. A high percentage of applicants to the Project SEED College Scholarship program have been participants at a DOE lab. These students have all indicated they had a desire to pursue a career in science.

Overall, based on the willingness of LANL and ORNL to continue hosting the program, the ECUT-DOE/Project SEED Student Scholars Partnership has been effective in establishing a comprehensive program where economically disadvantaged high school students, primarily from groups underrepresented in science, work directly with a mentor/researcher. The experience at these labs seems to be encouraging the students to pursue studies in science. 
Table of Gender and Ethnic Backgrounds of Participants in DOE/Project SEED Student Scholars Partnership

\begin{tabular}{|c|c|c|c|c|c|c|c|}
\hline & African American & Hispanic & White & American Indian & Other & Male & Female \\
\hline $\begin{array}{l}\text { Year I (1990) } \\
\text { Los Alamos } \\
\text { Oak Ridge }\end{array}$ & & $\begin{array}{l}6 \\
8\end{array}$ & $\begin{array}{l}1 \\
2\end{array}$ & 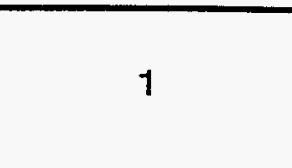 & & $\begin{array}{l}3 \\
6\end{array}$ & $\begin{array}{l}5 \\
4\end{array}$ \\
\hline $\begin{array}{l}\text { Year II (1991) } \\
\text { Los Alamos } \\
\text { Oak Ridge }\end{array}$ & 1 & $\begin{array}{c}8 \\
10\end{array}$ & 3 & & & $\begin{array}{l}4 \\
3\end{array}$ & $\begin{array}{l}7 \\
8\end{array}$ \\
\hline $\begin{array}{r}\text { Year III (1992) } \\
\text { Los Alamos - Summer I } \\
\text { Summer II } \\
\text { Oak Ridge - } \\
\text { Summer I }\end{array}$ & 1 & $\begin{array}{c}8 \\
6 \\
10\end{array}$ & $\begin{array}{l}1 \\
3\end{array}$ & 2 & & $\begin{array}{l}5 \\
1 \\
3\end{array}$ & $\begin{array}{c}6 \\
5 \\
11\end{array}$ \\
\hline $\begin{array}{r}\text { Year IV (1993) } \\
\text { Los Alamos - Summer I } \\
\text { Summer II } \\
\text { Oak Ridge - Summer I } \\
\text { Summer II }\end{array}$ & & $\begin{array}{c}9 \\
3 \\
12\end{array}$ & $\begin{array}{l}3 \\
3\end{array}$ & $\begin{array}{l}1 \\
1\end{array}$ & 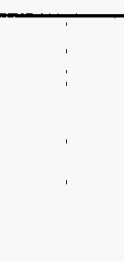 & $\begin{array}{l}5 \\
3 \\
5\end{array}$ & $\begin{array}{c}5 \\
1 \\
10 \\
3\end{array}$ \\
\hline $\begin{array}{r}\text { Year V (1994) } \\
\text { Los Alamos - Summer I } \\
\text { Summer II } \\
\text { Oak Ridge - Summer I } \\
\text { Summer II }\end{array}$ & 1 & $\begin{array}{l}7 \\
3 \\
8 \\
2\end{array}$ & $\begin{array}{l}2 \\
3\end{array}$ & & 1 & $\begin{array}{l}5 \\
3 \\
3 \\
2\end{array}$ & $\begin{array}{l}4 \\
7 \\
3\end{array}$ \\
\hline TOTALS & 3 & 100 & 21 & 5 & $\begin{array}{c}1 \\
130\end{array}$ & 51 & $\begin{array}{c}79 \\
130\end{array}$ \\
\hline
\end{tabular}

